\title{
Atmospheric Hydrodeoxygenation of bio-oil oxygenated model compounds; a review
}

Hamed Pourzolfaghar ${ }^{\mathrm{a}}$, Faisal Abnisa ${ }^{\mathrm{a}}$,Wan Mohd Ashri Wan Daud ${ }^{\mathrm{a} *}$, Mohamed Kheireddine Aroua $^{\mathrm{b}, \mathrm{c}}$

${ }^{a}$ Chemical Engineering Department, Faculty of Engineering, University Malaya, 50603 Kuala Lumpur, Malaysia

${ }^{\mathrm{b}}$ Centre for Carbon Dioxide Capture and Utilization (CCDCU), School of Science Technology, Sunway University, Bandar Sunway, 47500

Petaling Jaya, Malaysia

'Department of Engineering, Lancaster University, Lancaster, LA1 4YW, UK.

*Corresponding author. Tel.: +60 3 79675297; fax: +60 379675319 .

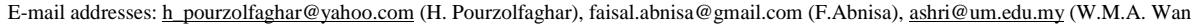

Daud), kheireddinea@sunway.edu.my (M.K. Aroua)

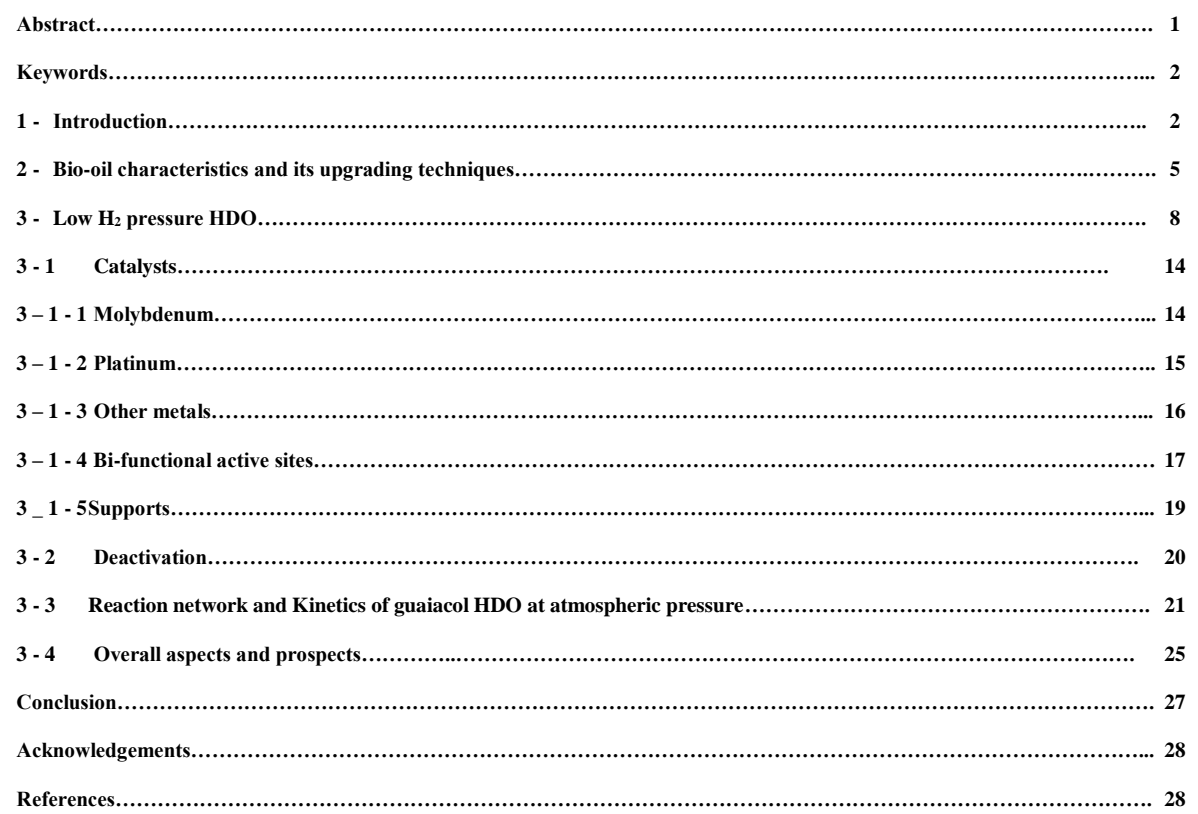

\section{Abstract}

Hydrodeoxygenation (HDO) of various bio oil oxygenated model compounds in low $\mathrm{H}_{2}$ pressure has been discussed in this study. Because of the high yield of aromatic mixtures in bio-oil, they carry great potential for fuel efficiency. Nevertheless, due to its high viscosity, abundance of 
acid, and heteroatom contaminants, the bio-oil ought to be upgraded and hydrotreated in order to be applied as an alternative fuel. A continuous low $\mathrm{H}_{2}$ pressure HDO of bio-oil is favored as it could be simply integrated with conventional pyrolysis systems, functioning at low pressures, as well as supporting a flexible plan for serial processing in respective bio-refineries. Additionally, such a process is cheaper and safer in comparison with the high pressure set ups. This review meticulously elaborates on the operation conditions, challenges, and opportunities for using this process in an industrial scale. The operating temperature, the $\mathrm{H}_{2}$ flow ratio, the active site, and the catalyst stability are some important factors to be considered when it is intended to reach a high conversion efficiency for the $\mathrm{HDO}$ in low $\mathrm{H}_{2}$ pressure.

\section{Keywords:}

Low pressure/Atmospheric $\mathrm{H}_{2}$ Hydrodeoxygenation; Fast pyrolysis oil; Bio oil upgrading; Guaiacol; Phenolic compounds

\section{1- Introduction}

Fast pyrolysis is the most promising thermochemical process among the other procedures to directly produce liquid from lignocellulosic biomass in high yield of up to wt. $\% 75 \%$, commonly referred to as bio-oil. Likewise, it has become of considerable interest due to its moderate operating temperature of around $773 \mathrm{~K}$ and very short reaction time of up to 2 s. (1-6). Bio-oil is generally a mixture of primarily phenolic oligomers derived from lignin in an aqueous phase comprising predominantly carbohydrate derived compounds (7-10). Several deteriorating properties such as high acidity, low higher heating value (HHV), high viscosity, poor storage stability and others have made bio-oil undesirable to instant usage as high grade fuels, mainly 
due to high amounts of oxygenated compounds as well as complex mixtures of chemical compounds (11-13).

Accordingly, upgrading the crude bio-oil has been acknowledged as the foremost challenge for production of competitive alternatives of petroleum fuels and also chemical feedstock in the chemical industry (14). Hydrodeoxygenation (HDO) and catalytic cracking with zeolite are the two main processes for bio-oil upgrading (15-17). The former is a hydrogenolysis route which uses high hydrogen pressure to exclude oxygen from oxygenated compounds, resulting a high grade product compared to crude bio-oil (10). In the latter process, different kinds of zeolites (HZSM-5, H-mordenite, H-Y, MgAPO-36, SAPO-11, ZnHZSM-5, etc.) are applied for the deoxygenation process without demanding hydrogen (18-22). Due to numerous drawbacks associated with catalytic cracking with zeolite such as the catalyst's very short lifetime, low grade products and a low $\mathrm{H} / \mathrm{C}$ ratio, $\mathrm{HDO}$ is evaluated as the most efficient route for upgrading crude bio-oil $(23,24)$.

The hydrodeoxygenation process could be classified into two chief routes; high pressure HDO and atmospheric HDO. High pressure HDO utilizes high pressure of hydrogen to remove oxygen atoms from the oxygenated compounds as well as hydrogenation of aromatic rings. It can minimize the oxygen contents of several classes of oxygenated groups including esters, phenols, aldehydes, acids, ketons, etc. Depending on the composition of the organic compound, many reactions can occur during this process, among which hydrogenation, decarboxylation, dehydration, hydrogenolysis, hydrocracking and so forth. Various categories of catalysts have been applied by researchers for high pressure HDO which present several characteristics (25- 
27). Among them, metals catalysts including precious and non-precious metals ( $\mathrm{Pt}, \mathrm{Pd}, \mathrm{Rh}, \mathrm{Ru}$, $\mathrm{Fe}, \mathrm{Ni}$, and $\mathrm{Cu}$ ) and also conventional hydrotreating catalysts such as Sulfided CoMo and NiMo have exhibited promising properties in HDO processes.

Atmospheric/low $\mathrm{H}_{2}$ pressure $\mathrm{HDO}$ is seems an ideal process since it can be easily integrated to existing plants of the pyrolysis of biomass, operates at near atmospheric pressure. This means no special equipment is needed to be designed and constructed for pressurizing purposes. In addition, the handling and feeding of bio-oil to the atmospheric reactors are more convenient and practicable in terms of safety. As the consequence, this process is considered cheaper and safer than high pressure HDO. Atmospheric HDO has the same procedure with conventional HDO process (high $\mathrm{H}_{2}$ pressure $\mathrm{HDO}$ ). Nonetheless, the catalyst type, process conditions, the reaction mechanism and function of hydrogen on the upgrading mechanism contrast with high pressure HDO. There has been a considerable upsurge in the number of researchers focusing on the current process during the present decade in order to overcome the challenges faced by this method including the unstable operation of the reactor, selectivity of the products, the catalyst deactivation and the like. Based on the reviewed articles in this field, the first study in low pressure hydrodeoxygenation of oxygenated compounds dates back to 2010 being executed by H.Y. Zhao et al (28). However, in the hope of using low pressure HDO in industrial scales, several scientists have concentrated on the low-pressure gas phase HDO of lignin-derived components to overcome its challenges.

This contribution thoroughly reviews the latest advances with reference to low consumption of $\mathrm{H}_{2}$ in bio-oil upgrading processes including the catalysts, the process conditions, the influence of 
$\mathrm{H}_{2}$ partial pressure, deactivation of the active sites, reaction mechanism and kinetics of the reaction. Similarly, the bio oil characteristics and its latest upgrading techniques as well as its applications have been reviewed meticulously.

\section{2- Bio-oil characteristics and its upgrading techniques}

Pyrolysis liquid, unprocessed bio oil, pyrolysis oil, and pyrolytic oil are some synonyms for biooil which can be produced from fast pyrolysis of lignocellulosic biomass with yield up to wt.\% $75 \%$ (29-32). Bio-oil is an intricate mixture comprising beyond 300 organic compounds including phenolics (phenol, catechol, anisole, syringol, guaiacol, etc.), oxygenates (alcohols, acids, esters, aldehydes and ketons), hydrocarbons (aromatics, alkene) furans, sugars, high molecular species (lignin derived oligomers, lignin, hemicellulose and cellulose) and water (33). The composition and yield of bio oil strictly depend on the pyrolysis process conditions (the heat transfer rate, the time, the temperature, the condensation, and the char removal efficiency, etc.), the moisture content, the particle size, and the feedstock chemical composition (34-37).

Oxygen is the most problematic element, as bio oils contains $10-40 \%$ oxygen. This influences the heating value (HV), acidity, viscosity, polarity, and homogeneity of the bio oil (38). The high water content leads to a polar nature for bio oils, resulting in immiscibility of bio oil with crude petroleum oil (25). Moreover, the high water content causes lower HV, which is around half of the value of heavy petroleum fuel oil. Acetic acid and formic acid are known as the main reasons for low $\mathrm{pH}$ of bio oils $(2-4)$ that cause harsh conditions for equipment used for processing, transport, and storage. Olefins, phenols, and aldehydes in bio oil are unsaturated, unstable, while easily forming macro-molecules through polymerization, particularly in the presence of acids, which will also grow the viscosity of bio oil and diminish liquidity. Considering some favorable 
properties of bio oil such as good lubricity, less toxicity, and greater bio degradation in comparison with heavy petroleum fuel oil, the application of bio oil is still limited by some undesired properties which are mainly due to oxygenated compounds.

Upgrading the bio oil is essential to elevate its properties for its practical application as liquid fuel (38). Productions of liquid fuels and raw chemicals as well as generation of heat and power are the main utilization of bio-oil produced from fast pyrolysis. As it can be perceived from Table 1, utilization of bio-oil could be categorized into direct and indirect ones. The direct usages include combustion of bio-oil in gas turbines, stirling engines, diesel engines, furnaces, and boilers to produce heat, electricity, etc. Table 1 tabularizes various direct usages of bio-oil. Some merits associated with the direct usage of bio-oil include $\mathrm{CO}_{2}$ neutral, very low sulfur content, easy transport, and storage. However, most of the investigation has been performed in laboratory scales and some inherent properties of bio-oil have made it challenging to use in large scale applications. There are two main options to solve such inherent problems, either to upgrade the bio-oil before direct usage or to configure the equipment used in direct usages such as diesel engine, stirling engine, gas turbine, and so forth. Substantial endeavors have been exerted on research and development related to the direct usage of bio-oil since it exhibits a much better prospect for high-efficiency energy production in comparison with the traditional biomass fuels. Indirect usages of bio-oil include upgrading bio-oil to liquid fuel and also extraction of chemicals from whole/fraction of bio-oil (Table 1). Bio-oil is a rich source of commercially valuable chemicals such as acetic acid, formic acid, furfural, levoglucosan, acetol, phenolics, etc. Many efforts have been exerted by researchers to find a proper route to recover these compounds from bio-oils from different sources (Table 1). Yet, there are significant complications to establish 
markets for these compounds including inefficient separation technologies, high production costs, and availability of appropriate refining methods (39-44).

Table 1. Bio- oil applications

\begin{tabular}{|c|c|c|c|c|c|}
\hline \multicolumn{6}{|c|}{ Direct usage of bio-oil } \\
\hline \multicolumn{2}{|c|}{ Process } & Product & Application & Country & Ref. \\
\hline \multicolumn{2}{|c|}{ Combustion in Furnace \& Boiler } & Energy & Heat \& Electricity & UK & (45) \\
\hline \multicolumn{2}{|c|}{ Combustion in Diesel engines } & Energy & Power generation & USA,UK & (46) \\
\hline \multicolumn{2}{|c|}{ Combustion in Gas turbines } & Energy & Power generation & Canada & (47) \\
\hline \multicolumn{2}{|c|}{ Combustion in Diesel engines } & Energy & Transportation & USA & (48) \\
\hline \multicolumn{2}{|c|}{ Combustion in Stirling engines } & Energy & Heat \& Electricity & Germany & (49) \\
\hline \multicolumn{6}{|c|}{ Indirect usage of bio-oil } \\
\hline \multicolumn{2}{|c|}{ Upgrading of bio oil to the conventional fuel } & Liquid fuel & Transportation & Global & (50) \\
\hline \multirow{11}{*}{ 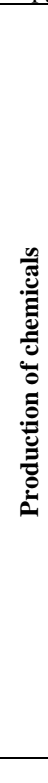 } & Catalytic pyrolysis & Furfural & $\begin{array}{l}\text { Pharmaceutical, } \\
\text { pesticide }\end{array}$ & Italy & (51) \\
\hline & Wet oxidation & Formic acid & $\begin{array}{l}\text { Antibacterial, } \\
\text { Preservative }\end{array}$ & Chile & (52) \\
\hline & Aqueous extraction & Glycolaldehyde & Meat browning & Netherlands & $(53)$ \\
\hline & $\begin{array}{l}\text { Separation, aqueous } \\
\text { extraction }\end{array}$ & $\begin{array}{l}\text { Glycoaldehyde, } \\
\text { glyceraldehydes, } \\
\text { diacetyl, aceton }\end{array}$ & $\begin{array}{l}\text { Food additive, } \\
\text { food flavore }\end{array}$ & Netherlands & (53) \\
\hline & Separation & whole bio-oil & Wood preservative & USA & (54) \\
\hline & Aqueous extract & Calcium salts & Road de- icers & Canada & (55) \\
\hline & Aqueous extraction & Acetic Acid & Specialty chemical & Korea & (56) \\
\hline & Solvent extraction & $\begin{array}{l}5- \\
\text { hydroxymethyl } \\
\text { furfural (HMF) }\end{array}$ & $\begin{array}{l}\text { Fine chemicals, } \\
\text { plastics }\end{array}$ & - & (57) \\
\hline & Phase seperation & Levoglucosan & $\begin{array}{l}\text { Pharmaceutical, } \\
\text { food additive, } \\
\text { pesticides, } \\
\text { surfactants, and } \\
\text { polymers }\end{array}$ & Canada & $(58)$ \\
\hline & N/A & Methanol & - & UK & (59) \\
\hline & $\begin{array}{l}\text { 1- Solvent } \\
\text { fractionation } \\
\text { 2- Phase separation }\end{array}$ & $\begin{array}{l}\text { Phenolic } \\
\text { compounds }\end{array}$ & $\begin{array}{l}\text { Phenol- } \\
\text { formaldehyde } \\
\text { resin, smoky flavor } \\
\text { providing }\end{array}$ & Korea & $\overline{(60,61)}$ \\
\hline & Catalytic pyrolysis & Olefins & $\begin{array}{l}\text { Fibers, plastics, } \\
\text { clothing }\end{array}$ & USA & (62) \\
\hline
\end{tabular}

Intensive investigations have been executed on bio-oil upgrading topics resulting in development of several technologies including emulsification, steam reforming, supercritical fluids (SCFs), hydrotreating (hydrodeoxygenation), and catalytic cracking/ hydrogenolysis $(39,63)$. Several research papers have been discussed regarding the details, process conditions as well as 
advantages and disadvantages of the mentioned technologies $(25,39,64,65)$. Among them, hydrodeoxygenation (HDO) has gained the attention of many researchers since it is able to produce a large amount of light products (31). Furthermore, its ability to reach high conversion of oxygenated compounds to hydrocarbons with no $\mathrm{CO}_{2}$ emission as well as its technology compatibility with conventional hydrotreating technology has made this process (HDO) as the best choice for bio-oil upgrading (26).

HDO is a thermal process to eliminate oxygen atoms from organic compounds under high pressure of hydrogen with a catalyst. It can diminish oxygen contents of various kinds of oxygenated groups such as phenols, acids, aldehydes, esters, ketons, etc. Depending on the composition of the organic compound, many reactions can occur during this process such as hydrogenation, decarboxylation, dehydration, hydrogenolysis, hydrocracking, etc. The HDO general reaction stoichiometry can be written as (25):

$$
\mathrm{CH}_{1.4} \mathrm{O}_{0.4}+0.7 \mathrm{H}_{2} \rightarrow \mathrm{CH}_{2}+0.4 \mathrm{H}_{2} \mathrm{O}
$$

Where $\mathrm{CH}_{1.4} \mathrm{O}_{0.4}$ symbolizes the carbohydrate in the organic compound. Generally, high operating conditions such as high temperature (573-873 K) and pressure (1000-30000 kPa) have been reported in literature for HDO which is not energy efficient and economical (66). The high pressure has been defined as confirming a higher solubility of hydrogen in the oil and consequently a higher availability of hydrogen in the vicinity of the catalyst. This elevates the reaction rate and further diminishes coking in the reactor (67). 


\section{3- Low $\mathrm{H}_{2}$ pressure $\mathrm{HDO}$}

A continuous low or even atmospheric HDO of vapor-phase is preferred as it could be easily combined with conventional pyrolysis setups, operates at near atmospheric pressure, as well as enabling a flexible strategy for sequential processing in respective bio-refineries. Furthermore, it is cheaper and safer than high pressure set ups. Unstable operation of the reactor caused by pressure buildup in the upgrading reactor as well as catalyst deactivation caused by destructive components especially phenolic compounds are the main challenges of the researchers at low pressure conditions. What follows is a succinct account of the most outstanding process criteria being applied in recent studies $(68,69)$. As can be observed from Table 2, the criteria being discussed encompass the active phase, the support, $\mathrm{H}_{2}$ partial pressure, the temperature, the feed composition, efficiency, and major products. The subsequent section (Sub-chapter 3-1) elaborates precisely on the most essential process criterion, the active phase, which brings us better understanding of catalyst selection for atmospheric HDO. 
Table 2. The latest development systems for atmospheric $\mathrm{H}_{2}$ hydrodeoxygenation

\begin{tabular}{|c|c|c|c|c|c|c|c|c|c|c|}
\hline Entry & $\begin{array}{c}\text { Active } \\
\text { phase }\end{array}$ & Support & $\begin{array}{c}\mathbf{H}_{2} \text { partial } \\
\text { pressure } \\
(\mathbf{k p a})\end{array}$ & $\begin{array}{c}\mathbf{T} \\
(\mathbf{K})\end{array}$ & Feed Composition & $\begin{array}{c}\mathrm{X} \\
(\%)\end{array}$ & $\underset{\left(h^{-1}\right)}{\text { WHSV }}$ & Remarks & Major products & Ref \\
\hline 1 & $\mathrm{MoO}_{3}$ & & 19.6 & 673 & $\begin{array}{c}\text { Acetone } \\
\text { 2-hexanone } \\
\text { Cyclohexanone } \\
\text { Anisole } \\
\text { 2- methyl furan } \\
\text { 2,5-dimethylfuran }\end{array}$ & $\begin{array}{l}96.8 \\
81.2 \\
100 \\
65 \\
53.1 \\
43.4\end{array}$ & 14.70 & $\begin{array}{l}\mathrm{MoO}_{3} \text { displays great tolerance to water poisoning } \\
\text { and coke creation. } \\
\text { By calcination process, } \mathrm{MoO}_{3} \text { can easily be } \\
\text { regenerated fully. }\end{array}$ & $\begin{array}{c}\text { Propylene } \\
\text { Benzene } \\
\text { Pentenes } \\
\text { Hexenes }\end{array}$ & (70) \\
\hline 2 & $\mathrm{Mo}_{2} \mathrm{C}$ & & 104 & $533-553$ & $\begin{array}{c}\text { m-cresol, anisole, } 1,2- \\
\text { dimethoxybenzene, and } \\
\text { guaiacol }\end{array}$ & $>90$ & - & $\begin{array}{l}\text { The applied operation conditions and the catalyst } \\
\text { in this study can result to high product selectivity } \\
\text { to aromatics. }\end{array}$ & $\begin{array}{l}\text { Benzene } \\
\text { Toluene }\end{array}$ & (71) \\
\hline 3 & NiMo & $\mathrm{Al}_{2} \mathrm{O}_{3}$ & $20.68-103$ & 723.15 & Acetic acid & $60-65$ & 0.06 & $\begin{array}{l}\text { By elevating the partial pressure of } \mathrm{H}_{2} \text {, acid acetic } \\
\text { conversion rate increases. Maximum conversion } \\
\text { rate occurs at } \mathrm{H}_{2} \text { partial pressure } 103 \mathrm{kpa} \text {. }\end{array}$ & $\begin{array}{l}\text { Ethanol } \\
\text { Acetaldehyde } \\
\text { Acetone } \\
\text { Ethyl acetate }\end{array}$ & (72) \\
\hline 4 & $\mathrm{MoO}_{3}$ & & 140 & $593-623$ & $\begin{array}{l}\text { Phenol, m-cresol, } \\
\text { anisole, guaiacol, } \\
\text { diphenyl ether }\end{array}$ & $28.7-97.5$ & $0.002-0.035$ & $\begin{array}{l}\mathrm{MoO}_{3} \text { is capable of selectively converting model } \\
\text { compounds into aromatic hydrocarbons with high } \\
\text { yields under atmospheric } \mathrm{H}_{2} \text { pressures. }\end{array}$ & $\begin{array}{l}\text { Benzene } \\
\text { Toluene } \\
\text { Phenol } \\
\text { Methane } \\
\end{array}$ & (73) \\
\hline 5 & $\mathrm{Mo}_{2} \mathrm{C}$ & & 140 & $420-520$ & Anisole & - & 0.05 & $\begin{array}{l}\text { low reaction temperature, and low } \mathrm{H}_{2} \text { pressure } \\
\text { were required to break the phenolic } \mathrm{C}-\mathrm{O} \text { bond. }\end{array}$ & Benzene & (74) \\
\hline 6 & $\mathrm{MoO}_{3}$ & & 140 & 723 & Acetone, Guaiacol & 52 & $0.9-1.8$ & $\begin{array}{l}\text { The level of HDO of the biomass pyrolysis vapors } \\
\text { was not significant at temperatures below } 400{ }^{\circ} \mathrm{C} \text {. } \\
\text { At } 4500^{\circ} \mathrm{C} \text { catalyst temperature and } 93 \text { vol } \% \mathrm{H}_{2} \\
\text { concentration, the wood pyrolysis vapor was more } \\
\text { active toward cracking forming gas species } \\
\text { instead of performing the desired HDO forming } \\
\text { hydrocarbons. }\end{array}$ & $\begin{array}{l}\text { Phenol } \\
\text { Benzene } \\
\text { Propene } \\
\text { Propane }\end{array}$ & (75) \\
\hline 7 & $\mathrm{MoO}_{3}$ & $\begin{array}{l}\gamma-\mathrm{Al}_{2} \mathrm{O}_{3} \\
\mathrm{SiO}_{2} \\
\mathrm{TiO}_{2} \\
\mathrm{ZrO}_{2} \\
\mathrm{CeO}_{2}\end{array}$ & 140 & 593 & m-cresol & $8-78$ & $2.06-8.27$ & $\begin{array}{l}\text { The data from product distribution specify that the } \\
\text { deoxygenation process on all catalysts involved a } \\
\text { selective C-O bond cleavage rather than a path } \\
\text { involving hydrogenation/dehydration as observed } \\
\text { for supported noble metals. }\end{array}$ & Toluene & (76) \\
\hline 8 & Pt & $\gamma-\mathrm{Al}_{2} \mathrm{O}_{3}$ & $0-140$ & 573 & Guaiacol & - & $9.9-20$ & $\begin{array}{l}\text { By elevating the hydrogen partial pressure, } \\
\text { selectivity for HDO enhanced gradually. }\end{array}$ & anisole, phenol. & (77) \\
\hline 9 & $\mathrm{Pt}$ & \begin{tabular}{|l}
$\mathrm{HBETA}$ \\
$\mathrm{SiO}_{2}$
\end{tabular} & 140 & 673 & Anisole & $80-100$ & 0.25 & $\begin{array}{l}\text { Rate of HDO and methyl transfer reactions were } \\
\text { accelerated by addition of Platinum to the zeolite. } \\
\text { This results to lower hydrogen consumption as } \\
\text { well as lower carbon losses as methane. }\end{array}$ & \begin{tabular}{|c|} 
benzene, \\
toluene, xylenes
\end{tabular} & (78) \\
\hline 10 & $\mathrm{Pt}$ & $\mathrm{Al}_{2} \mathrm{O}_{3}$ & 140 & 573 & Guaiacol & - & 7 & $\begin{array}{l}\text { The results indicate that there is no reaction in the } \\
\text { absence of hydrogen }\end{array}$ & $\begin{array}{l}\text { Anisole } \\
\text { Benzene } \\
\text { toluene }\end{array}$ & (79) \\
\hline
\end{tabular}




\begin{tabular}{|c|c|c|c|c|c|c|c|c|c|c|}
\hline 11 & $\mathrm{Pt}$ & $\mid \begin{array}{l}\mathrm{MgO} \\
\gamma-\mathrm{Al}_{2} \mathrm{O}_{3}\end{array}$ & 140 & 573 & Guaiacol & 70 & 11 & $\begin{array}{l}\mathrm{Pt} / \mathrm{MgO} \text { catalyzed the formation of the cyclic } \\
\text { deoxygenated product cyclopentanone at a } \\
\text { relatively high selectivity along with C4 } \\
\text { hydrocarbons and carbon monoxide. }\end{array}$ & $\begin{array}{l}\text { phenol, catechol, } \\
\text { cyclopent-anone }\end{array}$ & $(80)$ \\
\hline 12 & $\mathrm{Pt}$ & $\mathrm{Al}_{2} \mathrm{O}_{3}$ & 40 & 573 & $\begin{array}{l}\text { Guaiacol, anisole, 4- } \\
\text { methylanisole, } \\
\text { cyclohexanone }\end{array}$ & & $0.01-0.12$ & $\begin{array}{l}\text { Metal function and hydrogen are essential factors } \\
\text { for any hydrogenolysis reaction }\end{array}$ & $\begin{array}{l}\text { Phenol, } \\
\text { Benzene } \\
\text { Anisole }\end{array}$ & $(81)$ \\
\hline 13 & $\mathrm{Pt}$ & $\begin{array}{l}\gamma-\mathrm{Al}_{2} \mathrm{O}_{3} \\
\mathrm{SiO}_{2} \\
\mathrm{H}-\mathrm{BEA}\end{array}$ & 140 & 573 & m-cresol & $0-80$ & $0.09-12.5$ & $\begin{array}{l}\text { High acid sites density results to coke formation } \\
\text { which is detrimental for catalyst stability. }\end{array}$ & Toluene & (82) \\
\hline 14 & $\mathrm{Pt}$ & $\gamma-\mathrm{Al}_{2} \mathrm{O}_{3}$ & 140 & 573 & m-cresol & $74-90$ & $0.02-10$ & $\begin{array}{l}\text { By increasing the metal loading from } 0.05 \mathrm{wt} . \% \\
\text { to } 1.7 \mathrm{wt} \% \text {, high selectivity turned from light } \\
\text { hydrocarbons into toluene. }\end{array}$ & \begin{tabular}{|c|} 
Toluene \\
Benzene \\
Methylcyclohex \\
ane
\end{tabular} & (83) \\
\hline 15 & $\mathrm{Fe}$ & $\mathrm{SiO}_{2}$ & 70 & 673 & Guaiacol & 77.7 & 0.8 & - & $\begin{array}{l}\text { Benzene } \\
\text { Toluene }\end{array}$ & (84) \\
\hline 16 & $\mathrm{Fe}$ & $\begin{array}{l}\mathrm{SiO}_{2}, \\
\text { Activated } \\
\text { carbon }\end{array}$ & 70 & 673 & Guaiacol & 100 & 1.66 & $\begin{array}{l}\text { By increasing the metal loading from } 10 \mathrm{wt} . \% \text { to } \\
15 \mathrm{wt} . \% \text {, high selectivity turned from phenol and } \\
\text { cresols into benzene and toluene. }\end{array}$ & $\begin{array}{l}\text { Benzene, } \\
\text { Phenols }\end{array}$ & $(85)$ \\
\hline 17 & $\mathrm{Fe}$ & $\mathrm{SiO}_{2}$ & $20-90$ & $623-723$ & Guaiacol & 74 & $0.66-9$ & $\begin{array}{l}\text { Partial pressure of } \mathrm{H}_{2} \text { has negligible effect on } \\
\text { product distribution. }\end{array}$ & \begin{tabular}{|c|} 
benzene, \\
toluene, xylenes
\end{tabular} & $(86)$ \\
\hline 18 & $\mathrm{Ga}$ & $\begin{array}{l}\mathrm{HBETA} \\
\mathrm{SiO}_{2} \\
\mathrm{ZSM}_{-5}\end{array}$ & 140 & \begin{tabular}{|l|}
$673-823$ \\
\end{tabular} & m-cresol & $\begin{array}{c}80-85 \\
\text { (HBETA) }\end{array}$ & $0.04-0.5$ & $\begin{array}{l}\text { Without hydrogen partial pressure, the } \\
\text { hydrogenolysis process is quickly depleted. }\end{array}$ & \begin{tabular}{|c|} 
toluene, \\
benzene, xylene,
\end{tabular} & (87) \\
\hline 19 & $\mathrm{Ru}$ & $\mathrm{TiO}_{2}$ & 58 & 673 & $\begin{array}{l}\text { Biomass pyrolysis } \\
\text { vapors }\end{array}$ & - & $0.1-0.15$ & $\begin{array}{l}\text { With methoxy methyl groups transferred to the } \\
\text { ring, the phenolic compounds in the bio-oil were } \\
\text { transformed to less oxygenated compounds. }\end{array}$ & - & (88) \\
\hline 20 & W & Carbon & 140 & 653 & propanol/propanal & - & 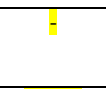 & $\begin{array}{l}\text { The catalyst is very selective in breaking the } \mathrm{C}- \\
\mathrm{O} / \mathrm{C}=\mathrm{O} \text { bond of propanol and propanal, resulting } \\
\text { to the production propene as the main product. }\end{array}$ & propene & (89) \\
\hline 21 & $\mathrm{Ni}$ & \begin{tabular}{|l|l}
$\mathrm{Al}_{2} \mathrm{O}_{3}$ \\
$\mathrm{SiO}_{2}$ \\
$\mathrm{HZSM}-5$ \\
$\mathrm{ZSM} 55$
\end{tabular} & 100 & \begin{tabular}{|l|}
$488-533$ \\
\end{tabular} & 1-octanol & 87.4 & $2.5-10$ & $\begin{array}{l}\text { Decreasing of pressure and WHSV, and also } \\
\text { increasing of nickel loading and the reaction } \\
\text { temperature resulted to increase in the conversion } \\
\text { rate. }\end{array}$ & Octenes & (90) \\
\hline 22 & $\begin{array}{l}\mathrm{Zn} \\
\mathrm{Ce} \\
\mathrm{Ni}\end{array}$ & $\mathrm{Al}_{2} \mathrm{O}_{3}$ & $0-140$ & 838 & $\begin{array}{l}\text { Sunflower stalk } \\
\text { bio-oil }\end{array}$ & 92 & 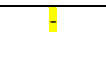 & $\begin{array}{l}2.5 \mathrm{wt} \% \text { metal }(\mathrm{Zn}, \mathrm{Ce} \text { or } \mathrm{Ni}) \text { loading on the } \\
\text { support exhibited the highest catalyst selectivity } \\
\text { and activity. }\end{array}$ & $\begin{array}{l}\text { Benzene } \\
\text { Toluene } \\
\text { Xylene }\end{array}$ & (91) \\
\hline 23 & $\begin{array}{l}\mathrm{Cu} \\
\mathrm{Fe} \\
\mathrm{Pd}\end{array}$ & Carbon & 140 & $523-723$ & Guaiacol & 65 & $4-20$ & $\begin{array}{l}\text { Base metal catalysts exhibit lower activity than } \\
\text { the precious metal catalysts, but selectively form } \\
\text { benzene along with small amounts of toluene, }\end{array}$ & $\begin{array}{l}\text { Toluene } \\
\text { Benzene }\end{array}$ & (92) \\
\hline
\end{tabular}




\begin{tabular}{|c|c|c|c|c|c|c|c|c|c|c|}
\hline & $\begin{array}{l}\mathrm{Pt} \\
\mathrm{PdFe} \\
\mathrm{Ru}\end{array}$ & & & & & & & $\begin{array}{l}\text { trimethylbenzene (TMB), and cresol without } \\
\text { forming ring saturated or ring-opening products. }\end{array}$ & & \\
\hline 24 & $\begin{array}{l}\mathrm{Pt}(\mathrm{Co}, \\
\mathrm{Ni})\end{array}$ & $\gamma-\mathrm{Al}_{2} \mathrm{O}_{3}$ & $\begin{array}{l}50 / 50\left(\mathrm{H}_{2} \text { to }\right. \\
\left.\mathrm{N}_{2} \text { ratio }\right)\end{array}$ & 533 & m-cresol & 38 & $\begin{array}{l}0-140 \mathrm{~W} / \mathrm{F} \\
\text { (gcat.h/mol) }\end{array}$ & $\begin{array}{l}\text { The additions of } \mathrm{Ni} \text { and } \mathrm{Co} \text { into Platinum } \\
\text { modified the product distribution as well as } \\
\text { improving the overall } \mathrm{HDO} \text { conversion. }\end{array}$ & $\begin{array}{c}\text { toluene, } \\
\text { methylcyclohexa } \\
\text { ne. }\end{array}$ & (93) \\
\hline 25 & $\mathrm{Pt}, \mathrm{Sn}$ & monolith & 101 & 673 & Anisole, Guaiacol & $\begin{array}{c}74 \\
\text { (anisole) } \\
90 \\
\text { (guaiacol) }\end{array}$ & $0.42-3.85$ & $\begin{array}{l}\text { In case of CNFs coating, surface area of the } \\
\text { monolith increased dramatically (more than } 10 \\
\text { times), which results to a higher metal loading in } \\
\text { active phase incorporation. }\end{array}$ & Phenol, benzene & (94) \\
\hline 26 & $\mathrm{Ni} / \mathrm{P}$ & $\mathrm{SiO}_{2}$ & 101 & 573 & Guaiacol & - & 10.68 & $\begin{array}{l}\text { Maximum deactivation rate }(78 \%) \text { of guaiacol } \\
\text { belongs to } \mathrm{Ni} / \mathrm{P}=1 \text { sample whereas the } \mathrm{Ni} / \mathrm{P}=3 \\
\text { sample had the lowest. }\end{array}$ & - & (95) \\
\hline 27 & $\begin{array}{l}\mathrm{Ni}_{2} \mathrm{P} \\
\mathrm{CO}_{2} \mathrm{P} \\
\mathrm{Fe}_{2} \mathrm{P} \\
\mathrm{WP} \\
\mathrm{MoP} \\
\end{array}$ & $\mathrm{SiO}_{2}$ & 112 & 573 & Guaiacol & $\begin{array}{l}80 \\
70 \\
64 \\
60 \\
54\end{array}$ & 0.37 & $\begin{array}{l}\text { The activity order of the applied catalysts for } \\
\text { guaiacol } \mathrm{HDO} \text { are: } \mathrm{Ni}_{2} \mathrm{P}>\mathrm{Co}_{2} \mathrm{P}>\mathrm{Fe}_{2} \mathrm{P}, \mathrm{WP}, \mathrm{MoP} \text {. }\end{array}$ & Phenol, benzene & (28) \\
\hline 28 & $\mathrm{Pd}-\mathrm{FeO}_{\mathrm{x}}$ & $\mathrm{SiO}_{2}$ & 100 & $573-623$ & Furan & 100 & - & $\begin{array}{l}\text { Using } 5 \% \mathrm{Pd}-2.5 \% \mathrm{FeOx} / \mathrm{SiO}_{2} \text { as catalyst resulted } \\
\text { to } 100 \% \text { conversion of furan. }\end{array}$ & \begin{tabular}{l|} 
Methyl-decane \\
Methyl-nonane
\end{tabular} & (96) \\
\hline 29 & $\mathrm{Ni}_{2} \mathrm{P}$ & \begin{tabular}{|l} 
Alumina, \\
Zirconia, \\
Silica
\end{tabular} & - & 573 & Guaiacol & - & $0.67-5.34$ & $\begin{array}{l}\mathrm{Ni}_{2} \mathrm{P} / \mathrm{SiO}_{2} \text { enhances } \mathrm{DMO} \text { and } \mathrm{DDO} \text { reactions, } \\
\text { while } \mathrm{Ni}_{2} \mathrm{P} / \mathrm{ZrO}_{2} \text { and } \mathrm{Ni}_{2} \mathrm{P} / \mathrm{Al}_{2} \mathrm{O}_{3} \text { promote DME. }\end{array}$ & $\begin{array}{c}\text { catechol, } \\
\text { anisole, cresol, } \\
\text { phenol, benzene, } \\
\text { cyclohexanone, } \\
\text { cyclohexanol } \\
\end{array}$ & (97) \\
\hline 30 & $\mathrm{Ni}_{2} \mathrm{P}$ & $\mathrm{SiO}_{2}$ & 112 & 573 & Guaiacol & 100 & 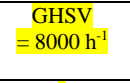 & $\begin{array}{l}\text { Selectivity profile by using this catalyst is } \\
\text { pentenes as primary products, 2-pentanone as a } \\
\text { secondary product, and pentane as a final product. }\end{array}$ & $\begin{array}{l}\text { Phenol } \\
\text { benzene }\end{array}$ & (98) \\
\hline 31 & $\mathrm{Ni}_{2} \mathrm{P}$ & $\mathrm{SiO}_{2}$ & 140 & 573 & 2-MTHF & - & T & $\begin{array}{l}\text { The } \mathrm{Ni}_{2} \mathrm{P} \text { catalyst is outstanding in producing } \\
\text { desired alkanes in the HDO of the biomass model } \\
\text { compound 2-methyltetrahydrofuran. }\end{array}$ & $\begin{array}{c}\text { n-butane } \\
\text { n-pentane }\end{array}$ & (99) \\
\hline
\end{tabular}


As it can be observed from Table 2, various kinds of supports have been applied in atmospheric $\mathrm{HDO}$ of bio-oil oxygenated compounds including $\mathrm{SiO}_{2}, \gamma-\mathrm{Al}_{2} \mathrm{O}_{3}$, Zeolites, carbon, $\mathrm{TiO}_{2}, \mathrm{ZrO}_{2}$, $\mathrm{MgO}, \mathrm{CeO}_{2}$, and monolith. Based on Table 2, $\mathrm{H}_{2}$ partial pressure fluctuates from 0 to 140 in different studies. In most of the cases, the balance gas is $\mathrm{N}_{2}$. The majority of researches has acknowledged that the higher partial pressure, the higher selectivity. The temperature fluctuates between $420 \mathrm{~K}$ and $838 \mathrm{~K}$, while the prevalent temperature is $573 \mathrm{~K}$. Taking into account the feed composition, it is realized that guaiacol is the most common model compound applied in these papers. However, various kinds of feeds have been used in this process including m-cresol, anisole, 2-hexanone, cyclohexanone, phenol, pyrolysis bio-oil vapors, furan, propanol, 2-MTHF, etc. Based on the mentioned feeds in this process, certain main products are expected such as benzene, toluene, propene, phenols, and others.

Reactors play an essential role in the chemical profile and yield of upgraded-bio-oil from pyrolysis vapors since it associates with the heating rate of system, heat transfer method, residence time of volatiles and conversion efficiency of oxygenated compounds (100). Each reactor has known advantages and disadvantages in operation and scaling. Fixed-bed reactor is the mostly used reactor in atmospheric HDO system (75). For those reactions in need of high temperature, the staged reactor can be used, which can adjust the reaction temperature to achieve the best catalytic effect and the lowest rate of catalyst deactivation (101). Batch reactors are applying in the HDO investigations when intermediate products are needed or fundamental studies are the objective of the studies. 


\section{3-1 HDO Catalysts}

Selection of a stable and active catalyst is crucial since it should overcome specifics operation conditions such as low $\mathrm{H}_{2}$ pressure and moderate to high temperatures. Until now, various kinds of catalysts have been tested in this process such as metal oxides, transition metal sulfides, phosphides, precious metals, etc. Characterization of the applied catalysts are meaningful since it helps to understand the common nature of each catalyst facing different bio oil model oxygenated compounds. To suit this purpose, almost all the so far applied catalysts for low $\mathrm{H}_{2}$ pressure HDO have been reviewed and discussed in the following sections.

\section{3-1-1 Molybdenum}

Molybdenum has been used by many researchers for HDO of various oxygenated components such as 2,5-dimethylfuran, 1,2-dimethoxybenzene, 2-methylfuran, diphenyl ether, 2hexanonephenol, acetic acid, m-cresol, cyclohexanone, acetone, guaiacol, and anisole (28,70,71,73-75,102). T. Prasomsri et al. (28) reported that $\mathrm{MoO}_{3}$ effectively converts bio-mass derived oxygenated compounds (Acetone, 2-hexanone, Cyclohexanone, Anisole, 2- methyl furan, 2,5-dimethylfuran) into unsaturated hydrocarbons (Propylene, Benzene, Pentenes, and Hexenes). According to their results, $\mathrm{MoO}_{3}$, at low $\mathrm{H}_{2}$ pressures, converts Phenolics and cyclic ketons to aromatics, and cyclic ethers and linear ketons to olefins with high yield. In another study by T.Prasomsri et al. (73), it was pinpointed that $\mathrm{MoO}_{3}$ is capable of selectively converting various oxygenated compounds to aromatic hydrocarbons without ring saturated products. The results revealed that $\mathrm{MoO}_{3}$ specifically cleaves phenolic Ph-OMe (CAromatic and OMethoxy) bond over the weaker aliphatic Ph-o-Me (OPhenolate and CMethoxy) bond which results in higher aromatic products. G. Zhou et al. (75) recently studied the atmospheric HDO of two bio- 
oil model compounds as well as a real biomass vapor in a fixed bed catalyst reactor at $773 \mathrm{~K}$.

They found that the best process conditions for conversion of the real biomass pyrolysis vapor are $723 \mathrm{~K}$ and $89 \%$ vol $\mathrm{H}_{2}$ concentration resulting in $16.2 \mathrm{wt} \%$ organic liquid with $11.5 \mathrm{wt} \%$ oxygen content. They also overstated that water inhibition, steric hindrance effects, and strong adsorption of pyrolysis vapor molecules to the catalyst active sites are the main reasons for harder upgrading of the pyrolysis vapor in comparison with the model compounds.

\section{3-1-2 Platinum}

Platinum is another frequently used metal as an active site for atmospheric HDO of model compounds. T. Nimmanwudipong et al.(77) studied the conversion of a model compound using platinum supported on Alumina. They found that the platinum function catalyzes the hydrogenolysis and hydrogenation reactions while the alumina support catalyzes the transalkylation reaction. From the experiments results, they concluded that the HDO selectivity rises with decreasing temperature elevating $\mathrm{H}_{2}$ partial pressure. In another study by T.Nimmanwudipong et al. (79), a comparative study was undertaken by using $\mathrm{Pt}_{2} / \mathrm{Al}_{2} \mathrm{O}_{3}$ with $\mathrm{H}_{2}$, HY zeolite, and $\mathrm{Pt} / \mathrm{Al}_{2} \mathrm{O}_{3}$ without $\mathrm{H}_{2}$ as the catalyst. Their results indicated that $\mathrm{H}_{2}$ is significant for oxygen removal from guaiacol. Also, the acidic catalysts without metal function (HY zeolite) produces similarly to those identified in the conversion catalyzed by the $\mathrm{Pt} / \mathrm{Al}_{2} \mathrm{O}_{3}$ in the absence of $\mathrm{H}_{2}$ (only transalkylation products). T. Nimmanwudipong et al.(80) further studied the HDO of guaiacol catalyzed by $\mathrm{Pt} / \mathrm{MgO}$ in atmospheric $\mathrm{H}_{2}$ pressure. The study results could be summarized as follows: (I) the selectivity to deoxygenated products in the reactions on $\mathrm{Pt} / \mathrm{MgO}$ was higher, almost double the value achieved with $\mathrm{Pt} / \mathrm{C}-\mathrm{Al}_{2} \mathrm{O}_{3}$, (II) sequential reactions (ring opening, ring closing, and decarbonylation) occurred on $\mathrm{Pt} / \mathrm{MgO}$, (III) $\mathrm{Pt} / \mathrm{MgO}$ catalyzed the 
formation of cyclopentanone at a relatively high selectivity, (IV) basic supports had higher conversion efficiency rather than acidic ones for noble metal hydrodeoxygenation catalysts. Ron C.Runnebaun et al. (81) scrutinized HDO of model compounds representative of lignin-derived bio oils such as guaiacol, anisole, 4-methylanisole, and cyclohexane using $\mathrm{Pt} / \gamma-\mathrm{Al}_{2} \mathrm{O}_{3}$ as the catalyst. Here it was found that when selective deoxygenation is a goal, partial pressure of $\mathrm{H}_{2}$ plays an important role in increasing the conversion efficiency. They also pointed out that $\gamma$ $\mathrm{Al}_{2} \mathrm{O}_{3}$ is not active for oxygen removal reactions and only catalyzes the transalkylation reactions.

\section{3-1-3 Other metals}

Lately, some transition/post-transition metal based catalysts such as Fe, Ga, W, and Ni have been employed by some researches $(84-87,89,90)$. R.N. Olcese et al. (84-86) investigated HDO of guaiacol over $\mathrm{Fe} / \mathrm{SiO}_{2}$, concluding that $\mathrm{Fe} / \mathrm{SiO}_{2}$ is an active and selective catalyst for the conversion of guaiacol even at high temperatures $[673 \mathrm{~K}]$. Although, $\mathrm{Fe} / \mathrm{SiO}_{2}$ is less active in comparison with the co-based catalysts, it is a more versatile catalyst. It also enjoys the benefits of being low-cost and environmental friendly. A. Ausavasukhi et al. (87) studied HDO of mcresol using gallium $(\mathrm{Ga})$ modified catalysts. They found that the yield of the desired products such as toluene and benzene undergoes a rise with $\mathrm{Ga}$ content, $\mathrm{H}_{2}$ partial pressure, space time (W/F), and reaction temperature. According to their results, $\mathrm{SiO}_{2}$ is not a proper support for Ga due to its inability to stabilize suitable Ga species which are the active sites for hydrogenolysis under atmospheric $\mathrm{H}_{2}$ flow. In another study by V.C.S. Palla et al. (90), the supported Ni catalysts $\left(\mathrm{Ni} / \mathrm{SiO}_{2}, \mathrm{Ni} / \gamma-\mathrm{Al}_{2} \mathrm{O}_{3}\right.$, and $\left.\mathrm{Ni} / \mathrm{HZSM}\right)$ were examined in $\mathrm{HDO}$ of 1 -octanol as a model aliphatic alcohol of bio oil at atmospheric $\mathrm{H}_{2}$ pressure. Table 3 tabulates the products and their selectivity percentages. According to the results, Ni/ZSM55 has the highest conversion 
efficiency among the other catalysts. Furthermore, the main products of HDO of 1-Octanol are nHeptane, heptane, n-octane, octenes, DOE, and 1-octanal.

Table 3. The role of various supports on hydrodeoxygenation of 1-octanol (90)

\begin{tabular}{|l|l|l|l|l|l|l|l|}
\hline \multirow{2}{*}{ Catalyst } & Conversion & \multicolumn{6}{|c|}{ Selectivity, } \\
\cline { 3 - 8 } & rate & n-Heptane & Heptenes & n-octane & Octenes & 1-octanol & DOE \\
\hline $\mathrm{Ni} / \gamma-\mathrm{Al}_{2} \mathrm{O}_{3}$ & 45.1 & 50.9 & 24.9 & 0.7 & 0.4 & 10.7 & 10.1 \\
\hline $\mathrm{Ni} / \mathrm{SiO}_{2}$ & 43 & 52.7 & 32.8 & 0.3 & 0.2 & 10.8 & 2.6 \\
\hline $\mathrm{Ni} / Z \mathrm{ZM} 23$ & 40.2 & 8.2 & 0 & 5.9 & 73.2 & 6.2 & 6.5 \\
\hline $\mathrm{Ni} /$ ZSM55 & 61.5 & 10.6 & 0 & 4.0 & 69.5 & 6.2 & 6.9 \\
\hline
\end{tabular}

\section{3-1-4 Bi-functional active sites}

Bi-functional catalysts such as $\mathrm{Pt}-\mathrm{Co} / \gamma-\mathrm{Al}_{2} \mathrm{O}_{3}, \mathrm{Ni}_{2} \mathrm{P} / \mathrm{SiO} 2, \mathrm{Pd}-\mathrm{FeO} / \mathrm{SiO} 2, \mathrm{Ru} / \mathrm{TiO}_{2}$, etc. represent superior stabilities and activities among the other catalysts which can convert the oxygenated compounds through more than one reaction mechanism resulting in a surge in the yield of the desired products. M.A. Gonzalez-Borja and D.E. Resasco (94) elaborated on HDO of anisole and guaiacol using monolithic Pt-Sn catalysts at atmospheric pressure. The authors concluded that bimetallic Pt-Sn/CNF/Inconel catalyst is able to fully deoxygenate anisole and guaiacol at atmospheric pressure for a long time on stream (TOS). Nonetheless, the monometalic catalysts applied in this study (Pt/Inconel, and Sn/Inconel) deactivate much faster than the bimetallic catalysts and also have shorter TOS. In addition, P.T.M. Do et al. (93) investigated HDO of mcresol on $\mathrm{Pt} / \gamma-\mathrm{Al}_{2} \mathrm{O}_{3}, \mathrm{Pt}-\mathrm{Co} / \gamma-\mathrm{Al}_{2} \mathrm{O}_{3}, \mathrm{Pt}-\mathrm{Ni} / \gamma-\mathrm{Al}_{2} \mathrm{O}_{3}$ at near atmospheric $\mathrm{H}_{2}$ pressure. They reported that HDO proceeds through two successive routes; hydrogenation of aromatic rings on the metal sites and dehydration of intermediates on the support $\left(\gamma-\mathrm{Al}_{2} \mathrm{O}_{3}\right)$. Addition of $3 \mathrm{D}$ metals, including $\mathrm{Co}$ and $\mathrm{Ni}$, into the catalyst significantly improved the products (toluene, and methylcyclohexane) distribution and the conversion rate. In another study by N. Joshi and A. Lawal (72), pre-sulfided $\mathrm{NiO} / \mathrm{MoO}_{3} / \mathrm{Al}_{2} \mathrm{O}_{3}$ was used as catalyst for $\mathrm{HDO}$ of acetic acid. 
Acetaldehyde, ethyl acetone, and acetone are the main products of HDO of acetic acid at $723 \mathrm{~K}$

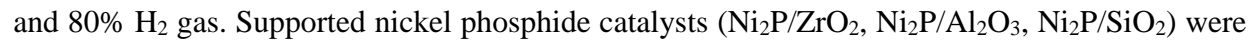
used in HDO of guaiacol by S. K. Wu et al. (97). According to the analysis results obtained from this study, $\mathrm{Ni}_{2} \mathrm{P} / \mathrm{ZrO}_{2}$ is the most whilst $\mathrm{Ni}_{2} \mathrm{P} / \mathrm{SiO}_{2}$ is the least reactive catalyst, based on the pseudo first order kinetics results at $573 \mathrm{~K}$. However, TOS results revealed that $\mathrm{Ni}_{2} \mathrm{P} / \mathrm{SiO}_{2}$ promotes direct deoxygenation (DDO) as well as DMO routes for removing oxygen, resulting in benzene and phenol, respectively. They established that $\mathrm{Ni}_{2} \mathrm{P} / \mathrm{SiO}_{2}$ is the most promising catalyst, in comparison with its counterparts, for HDO of Guaiacol in atmospheric pressure. In the other study conducted by S.K. Wu et al. (95), the effect of phosphorous composition of nickel phosphide catalysts was scrutinized. Using various initial Ni/P molar ratios, they prepared three catalysts with different active phases $\left(\mathrm{Ni}_{2} \mathrm{P}, \mathrm{Ni}_{12} \mathrm{P}_{5}\right.$, and $\left.\mathrm{Ni}_{3} \mathrm{P}\right)$. The authors reported that although $\mathrm{Ni}_{2} \mathrm{P}$ has the highest deactivation rate, its product distribution is more stable compared to the other catalysts, which is mainly due to its bi-functional nature (protonation on $\mathrm{PO}-\mathrm{H}$ and hydrogenation on $\mathrm{Ni}$ ). In a study by $\mathrm{S}$. Wan et al. (88), $5 \% \mathrm{Ru} / \mathrm{TiO}_{2}$ was applied for $\mathrm{HDO}$ of oak and switchgrass pyrolysis vapors at low $\mathrm{H}_{2}$ pressures. They found that noble metals play a role in generating vacancy sites on the support surface $\left(\mathrm{TiO}_{2}\right)$ that promotes ketonization besides its main role which is to function for deoxygenation. Furthermore, according to the Van krevel diagram results, catalytic treatment of the pyrolysis vapors contributed to a rise in $\mathrm{O} / \mathrm{C}$ and $\mathrm{H} / \mathrm{C}$ in the combined aqueous phase (0.93 and 1.92 respectively). In a very recent investigation by J. Yang et al. (103), a new bi-functional catalyst $\left(\mathrm{Pd}-\mathrm{FeO}_{\mathrm{X}} / \mathrm{SiO}_{2}\right)$ was used for atmospheric $\mathrm{HDO}$ of furfural. Based on their results, $5 \% \mathrm{Pd}-2.5 \% \mathrm{FeO}_{\mathrm{X}} / \mathrm{SiO}_{2}$ represents a full conversion of furfural with high efficiency of jet fuel range alkenes at $573 \mathrm{~K}-623 \mathrm{~K}$. The modification of $\mathrm{Pd} / \mathrm{SiO}_{2}$ with FeOX results in (I) restraining of the decarbonylation reactions, (II) lowering the coordination 
number of Pd-Pd species, (III) promoting the hydrogenation of carbonyl group over Pd, and (IV)

generating Pd-Fe alloy. All these effects contribute to a high HDO activity of the catalyst at atmospheric pressure.

\section{3-1-5 Supports}

Material carrier plays an essential role in catalytic preparation. Two main features should be considered in the selection of a support for at HDO; ability to activate oxygenated compounds and low affinity for carbon formation $(25,104)$.

Due to the presence of water in bio-oil, $\mathrm{Al}_{2} \mathrm{O}_{3}$ is an unsuitable support for this process since it will convert to boehmite in the presence of a large amount of water $(2,67,105)$. Formation of boehmite further results to the oxidation of metals on the catalysts that are inactive with respect to HDO and also could block other active sites on the catalysts. Furthermore, according to Popov et al (1), two third of the alumina covers with phenolic compounds at $400{ }^{\circ} \mathrm{C}$ that are potential carbon precursors.

As an alternative to $\mathrm{Al}_{2} \mathrm{O}_{3}, \mathrm{SiO}_{2}$ has been found to be a more promising support mainly due to its neutral nature features to a lower tendency for carbon formation compared to $\mathrm{Al}_{2} \mathrm{O}_{3}$ (28). $\mathrm{Al}_{2} \mathrm{O}_{3}$ dissociates phenol into more strongly adsorbed species on the acid sites, but $\mathrm{SiO}_{2}$ only interacts with phenol through hydrogen bonds (106). Additionally, Popov et al. (1) revealed that the concentration of adsorbed phenolic compounds on $\mathrm{SiO}_{2}$ was only $12 \%$ comparative to the concentration found on $\mathrm{Al}_{2} \mathrm{O}_{3}$. $\mathrm{TiO}_{2}, \mathrm{ZrO}_{2}$, and $\mathrm{CeO}_{2}$ also have been applied as the catalyst support in atmospheric HDO (76). They thought to have the potential to active oxygenated 
species on their surface and therefore increase activity. Henceforth, they seem attractive in the formulation of new catalysts.

\section{3-2 Deactivation}

According to the reviewed articles, carbon deposition on the catalyst surface is the main route of catalyst deactivation. Other mentioned causes including metal deposition, sintering of the catalyst, poisoning by water, phosphorous, nitrogen, etc., also happen at HDO at low hydrogen pressure. Lignin derived compounds, such as phenols, due to their great concentrations of unsaturated hydrocarbons elements, are greatly prone to formation of coke. The unsaturated hydrocarbon elements, typically react tightly with catalytic sites on the surface, limiting the access of other oxygenated compounds to the active sites. Some well-known factors for catalyst deactivation are the temperature, the catalyst acidity, the catalyst pore volume, and the space velocity which have been discussed thoroughly elsewhere (107-109). Following some recent discussions regarding low $\mathrm{H}_{2}$ pressure $\mathrm{HDO}$ catalyst deactivation has been reviewed.

In an attempt to find an effective and applicable HDO route as well as understanding the factors influencing the catalyst deactivation, T.Prasomsri et al (70) investigated HDO of acetone with $\mathrm{MoO}_{3}$ using low $\mathrm{H}_{2}$ pressure. They found that $\mathrm{H}_{2}$ partial pressure casts a strong effect on the catalyst performance and the catalyst deactivation profile. The increase in $\mathrm{H}_{2}$ partial pressure results in regenerating active oxygen vacancy sites while it avoids blocking of active sites by carbonaceous species (71).

R.N. Olcese et al. (84) performed a kinetic and modeling study for low $\mathrm{H}_{2}$ pressure HDO of guaiacol to aromatic compounds over $\mathrm{Fe} / \mathrm{SiO}_{2}$. They found that the plots for the values of 
kinetics constants of the selected reactions versus TOS fit very well with the following empirical law for the coke-induced catalytic deactivation;

$$
K=K^{0} \exp (\alpha t)
$$

In this equation $\mathrm{t}$ stands for the time in minutes, $\alpha$ denotes the coefficient for deactivation in min ${ }^{-}$ ${ }^{1}, \mathrm{~K}^{0}$ is the initial reaction rate, and $\mathrm{K}$ symbolizes the reaction rate in $\mathrm{kmol} /(\mathrm{s} . \mathrm{kg})$.

González-Borja, M. Á., and Resasco, D. E (94) reported that notwithstanding a high reactivity in a typical HDO process, it might have a high rate of catalyst deactivation that is only apparent in the distribution of products. For instance, they observed that the conversion of anisole yields benzene as the main end product, with phenol as the major intermediate, while o-cresol and toluene appear as minor products even after 125 TOS. It is whilst, in the case of guaiacol, after 125 TOS, phenol is the main end product.

In a study by Moon et al (110), they surveyed the catalyst deactivation in various pressures and temperatures. At $1 \mathrm{~atm}$, the reduction in reaction temperature dropped the HDO conversion from $80 \%$ to $60 \%$, but it was not completely recovered upon the temperature ramping, representing that the catalyst underwent deactivation possibly due to the partial oxidation of the catalyst surface or coke deposition. At 8 atm, the deactivation was not detected and the hydrodeoxygenation activity was retrieved upon the increase in temperature. These results propose that the hydrogenation route (the reaction mechanism at high pressures) is less susceptible to coke deposition or poisoning than the direct deoxygenation route (the reaction mechanism in atmospheric pressure).

\subsection{Reaction network and Kinetics of guaiacol HDO at atmospheric pressure}


The kinetics of HDO has been investigated by many researchers to better understand the HDO mechanism of pyrolysis oil $(111,112)$. However, the sparse reliable kinetic information of HDO of pyrolysis oil is reported due to the diversity of complex compositions of bio-oils (113); instead, a variety of studies explored the HDO kinetics of different model compounds which were found to be the significant compositions of bio-oils with a lower reactivity, such as guaiacol, phenols, furans, aldehydes and the like (112). The kinetics of HDO of guaiacol had received increasing attentions since it is the most representative model compound for the ligninderived bio-oil $(28,86,114,115)$. This is mainly due to the fact that guaiacol incorporates two types of $\mathrm{C}-\mathrm{O}$ bond that represent both lignin and many of its derivatives. Furthermore, the existence of guaiacol in bio oils remarkably affects the results of upgrading of bio oil mainly due to their low reactivity $(116,117)$. Compared to phenol, there is one more methoxy group attached to the aromatic ring. This small change makes the reaction network of guaiacol much more complex than the phenol (118). S.K. Wu et al (119) investigated the atmospheric HDO of guaiacol over $\mathrm{Ni}_{2} \mathrm{P}$ catalysts. According to their results obtained from the activity evaluation, they proposed a conceivable network for the reaction. Figure 1 represents a reaction network for the atmospheric guaiacol HDO over $\mathrm{Ni}_{2} \mathrm{P}$ catalysts. 


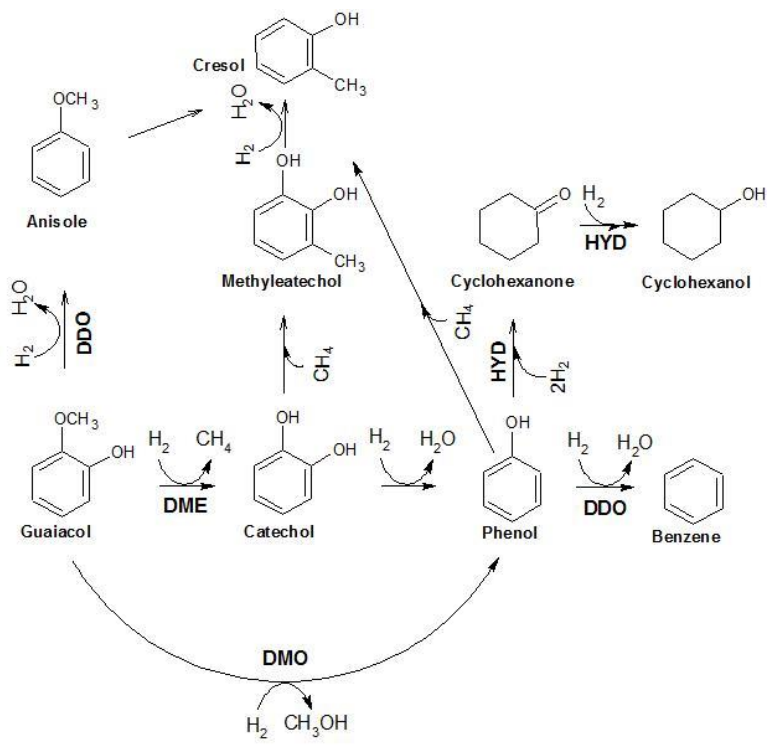

Figure 1. Proposed guaiacol HDO network at atmospheric $\mathrm{H}_{2}$ pressure (119)

Based on the proposed network, they found four possible reaction routes including Hydrodeoxygenation (HDO), Direct Deoxygenation (DDO), Demethoxylation (DMO), and Demethylation (DME). Among these four routes, DDO and DMO are the only oxygen-atom removal pathways. By comparing the other studies of guaiacol HDO at a low pressure environment, the authors found that the route of guaiacol DDO to anisole is a common point in these studies. According to the findings, they declared that $\mathrm{H}_{2}$ pressure is an essential factor to mediate the HDO network. T. Nimmanwudipung et al (77) carried out a study on catalytic HDO of guaiacol in a continuous tubular reactor over platinum supported on alumina. The results derived from the logarithmic plot of the experimental data (fraction of the guaiacol unconverted versus the inverse space velocity) showed apparent first order kinetics. $16.2 \mathrm{~L}$ (g of catalyst $)^{-1} \mathrm{~h}^{-1}$ is the pseudo first order rate constant for the guaiacol conversion using platinum as the catalyst. 
S.K. Wu et al (119) deployed the same approach to gain the rate constant for the conversion of guaiacol in a low $\mathrm{H}_{2}$ pressure. The authors applied supported Nickel phosphides as the catalysts. Compared to the above-mentioned study, an order of the magnitude smaller rate constant (1.5 (g catalyst $)^{-1} \mathrm{~h}^{-1}$ ) was achieved, indicating that platinum was much active for this type of reactions. The first order reaction kinetic was also reported in this study for guaiacol HDO.

However, other orders for the reaction kinetic of guaiacol $\mathrm{HDO}$ at the atmospheric $\mathrm{H}_{2}$ pressure have been reported. For instance, R. N. Olcese et al (84) surveyed guaiacol catalytic HDO over $\mathrm{Fe} / \mathrm{SiO}_{2}$ catalyst. They carried out the experiments in a fixed bed reactor at the atmospheric pressure. A gas mixture including guaiacol, $\mathrm{H}_{2} \mathrm{O}, \mathrm{CO}, \mathrm{CO}_{2}$ and $\mathrm{H}_{2}$ was applied in this study as the feed to simulate the real gas composition from the pyrolysis of the lignin. According to their offered reaction pathway derived by the experimental results, they proposed the following equation for guaiacol $\mathrm{HDO}$ at the atmospheric pressure:

$$
\frac{1}{1-n}\left(F_{i}^{1-n}-F_{0 i}^{1-n}\right)=-\frac{k(R T)^{n}}{Q^{n-1}} t
$$

$\mathrm{F}_{\mathrm{i}}, \mathrm{F}_{0 \mathrm{i}}, \mathrm{k}, \mathrm{R}, \mathrm{T}, \mathrm{Q}$ and $\mathrm{t}$ stand for the molar flow rate of the converted compound, the molar flow rate at the entrance of the catalyst bed, the kinetic constant, the molar gas constant, the temperature of the catalyst bed, the total volume flow rate of the gas phase and the space time, respectively. The authors reported that based on equation 2 , the apparent reaction rate can be assumed zeroth order since the molar flow rate of guaiacol, benzene, and toluene exhibit a linear evolution with the space time. The apparent zero order kinetics observed for all the reactions would indicate that the oxygenated species are strongly adsorbed through hydroxyl moieties with a high surface coverage. The second order for this reaction has been proposed by D. Gao et al 
(120). They performed a kinetic study based on five 5 sub-reactions for the guaiacol-hydrogen reaction over platinum as the catalyst;

$$
\begin{aligned}
& \text { guaiacol }+\mathrm{H}_{2} \stackrel{k_{1}}{\rightarrow} \text { catechol }+\mathrm{CH}_{4} \\
& \text { catechol }+\mathrm{H}_{2} \stackrel{k_{2}}{\rightarrow} \text { phenol }+\mathrm{H}_{2} \mathrm{O} \\
& \text { guaiacol }+2 \mathrm{H}_{2} \stackrel{k_{3}}{\rightarrow} \text { phenol }+\mathrm{MeOH} \\
& \text { guaiacol }+3 \mathrm{H}_{2} \stackrel{k_{4}}{\rightarrow} \text { cyclopentanone }+\mathrm{CH}_{4}+\mathrm{CO} \\
& \text { catechol }+2 \mathrm{H}_{2} \stackrel{k_{5}}{\rightarrow} \text { cyclopentanone }+\mathrm{CO}
\end{aligned}
$$

They also integrated the designed equation based on a plug-flow packed-bed reactor assumption and finally concluded that the good fitting was achieved when the reaction order was 2 . They explained that under the applied operation conditions, adsorption of guaiacol is the rate controlling and this is the most possible explanation for the second order reaction rate. Based on the various orders for HDO of guaiacol, it could be understood that the experimental conditions used, such as the catalyst, types of the reactors, the method of analysis and the like, will have an influence on the kinetic parameters obtained by different studies. Furthermore, selecting a proper kinetic model to predict the reaction order is critical. Three reaction models are commonly applied for this purpose including Langmuir-Hinshelwood, Rideal-Eley, and power-law models (120). Among them, however, the power-law kinetic model generally represents good fitting results and realistic kinetic parameters for this type of reactions.

\section{3-4 Overall aspects and prospect of low $\mathrm{H}_{2}$ pressure HDO}

Although recently a significant number of relevant studies have focused on the low $\mathrm{H}_{2}$ pressure HDO process of bio oil oxygenated compounds in the laboratory scale, further investigation is demanded to explore the integration of the current infrastructures of oil refinery for this process 
in an industrial prospective. Low $\mathrm{H}_{2}$ pressure $\mathrm{HDO}$ is a promising and attractive process since $\mathrm{H}_{2}$ consumption is one of the most paramount constituents which affects the total cost of end products in HDO of bio oils. Though, in this process, the most problematic challenge is finding a robust catalyst which is able to tolerate high processing temperature and stand against deactivation by coking and water poisoning. Consistent with the recent surveys, $\mathrm{MoO}_{3}$ is an outstanding catalyst representing high tolerance to coke formation and water poisoning (70). Further favorable catalysts for this process include $\mathrm{Ni}_{2} \mathrm{P} / \mathrm{SiO}_{2}, \mathrm{Pd}-\mathrm{FeO}_{\times} / \mathrm{SiO}_{2}, \mathrm{Fe} / \mathrm{SiO}_{2}$, and $\mathrm{Pt} / \mathrm{SiO}_{2}$. Among all the supports being used so far, $\mathrm{SiO}_{2}$ represents the best characteristics for the active sites in low $\mathrm{H}_{2}$ pressure HDO. C.R. Lee et al. (121) reported that the deoxygenation activity of an active site increases when more acidic sites are introduced. The authors reported that 2-methoxycyclohexanol is formed exclusively by hydrogenation of the benzene ring once the conversion is catalyzed by noble metals supported on nitric-acid-treated carbon black, but when the support is $\mathrm{SiO}_{2}-\mathrm{Al}_{2} \mathrm{O}_{3}$, which incorporates acidic sites, the main product is cyclohexane which is a desired product. Nevertheless, as it was mentioned in the catalyst deactivation section at an earlier point, the conversion rate does not reflect the efficiency of the applied catalyst since the main product alters from the deoxygenated ones to the oxygenated compounds although the conversion stays high. Therefore, the judgement should be based on the analytical results from the experiments as the conversion rate does not suffice. According to the literature, the main valuable products from HDO of bio oil oxygenate compounds are benzene, phenol, toluene, and anisole.

The selectivity and conversion rate of the fuels produced from upgrading bio-oil are vital features to consider, but depending on the process conditions, especially $\mathrm{H}_{2}$ pressure. By 
changing the $\mathrm{H}_{2}$ pressure, different product compositions with various conversion rates will be achieved. As yet, there are a few comparison studies on HDO of a model compound using a catalyst in atmospheric and high pressures of $\mathrm{H}_{2}$ to explore the exact impact of $\mathrm{H}_{2}$ pressure on this process.

In a study by Moon et al (110), they investigated the $\mathrm{HDO}$ of guaiacol using $\mathrm{Ni}_{2} \mathrm{P} / \mathrm{SiO}_{2}$ as the catalyst in 1 and 8 atmospheric pressure of $\mathrm{H}_{2}$ as well as various temperatures of the reaction to monitor the selectivity and efficiency of the process. $\mathrm{CO}$ chemisorption uptake measurement revealed after hydrodeoxygenation process, the loss of active sites is more pronounced for the catalyst tested at 1 atmosphere in comparison to the catalyst tested at 8 atmospheres. The decrease in the $\mathrm{CO}$ uptake was found to be $32 \%$ and $9 \%$ for the $\mathrm{Ni}_{2} \mathrm{P}$ samples tested at 1 and 8 atmospheres respectively. The authors found that at $1 \mathrm{~atm}$ guaiacol converts to benzene as the major products with a selectivity of $62 \%$, then anisole $(30 \%)$, cyclohexane $(7 \%)$, and phenol $(<1 \%)$ as minor products, with a guaiacol conversion of $83 \%$. Instead, at 8 atm the conversion of guaiacol resulted to cyclohexane (91\%) as the major component and benzene $(8 \%)$, anisole (1\%), and phenol $(1 \%)$ as minor products, with a guaiacol overall conversion of $100 \%$. Further investigation at elevated pressures (up to $15 \mathrm{~atm}$ ) proved the same trend, increasing the pressure leads to decrease in benzene production and simultaneously increase in cyclohexane production. The following overall conclusions have been made based on the Moon et al (2014) experimental results followed by DFT studies together with XAFS and in situ FTIR measurements.

- pre-hydrodeoxygenation and direct hydrodeoxygenation occur concurrently over the catalyst, in which the HDO of guaiacol frequently yields phenol or anisole in the early stage of reaction. 
- At $1 \mathrm{~atm}$, the direct hydrodeoxygenation pathway appears dominant to give benzene

- At 8 atm, the pre-hydrogenation pathway becomes prominent to form cyclohexane

- The active spots of the catalysts for the HDO of guaiacol can be proposed in terms of relative populations of $\mathrm{OH}$ or $\mathrm{H}$ groups on $\mathrm{P}$ or $\mathrm{Ni}$ sites of $\mathrm{Ni}_{2} \mathrm{P}$ surface, influencing whole reaction pathways.

- Direct deoxygenation pathway is preferred by the surface $\mathrm{OH}$ groups, whereas the prehydrogenation pathway is favored on the more reduced surface of the catalyst. Furthermore, high dispersion of the active sites will be of great importance in facilitating the hydrodeoxygenation process.

\section{Conclusion}

Atmospheric hydrodeoxygenation (HDO) of bio-oil/bio-derived oxygenated compounds in pyrolysis oils has been reviewed. The catalysts having a high activity for $\mathrm{HDO}$ at atmospheric $\mathrm{H}_{2}$ pressure as well as great potential to avoid carbon formation are of great challenge in this discipline. $\mathrm{MoO}_{3}, \mathrm{Ni}_{2} \mathrm{P} / \mathrm{SiO}_{2}, \mathrm{Pd}-\mathrm{FeOx} / \mathrm{SiO}_{2}, \mathrm{Fe} / \mathrm{SiO}_{2}$, and $\mathrm{Pt} / \mathrm{SiO}_{2}$ are the most promising catalysts efficiently upgrade oxygenated compounds (guaiacol, m-cresol, acetone, furan, 2methyl furan, 2,5-dimethylfuran, anisole, etc.) to higher octane index compounds. Based on this review, $573 \mathrm{~K}$ is the most proper temperature for atmospheric HDO since it maximizes the conversion rate while the coking is still low. However, in order to make this process affordable in an industrial scale in the future, many challenges have to be addressed meticulously through further studies include; lack of advanced kinetic studies to reveal an accurate mechanism of atmospheric HDO, optimizing the reaction conditions, and exploring developed catalysts. 


\section{Acknowledgment}

The authors gratefully acknowledge the financial support from GSP-MOHE (mo008-2015),

University of Malaya, Malaysia.

\section{References}

[1] Popov A, Kondratieva E, Mariey L, Goupil JM, El Fallah J, Gilson JP, Travert A, Maugé F. Bio-oil hydrodeoxygenation: Adsorption of phenolic compounds on sulfided (Co)Mo catalysts. J Catal [Internet]. 2013;297:176-86. Available from: http://dx.doi.org/10.1016/j.jcat.2012.10.005

[2] Elliott DC. Historical developments in hydroprocessing bio-oils. Energy and Fuels. 2007;21(3):1792-815.

[3] Limayem A, Ricke SC. Lignocellulosic biomass for bioethanol production: Current perspectives, potential issues and future prospects. Prog Energy Combust Sci [Internet]. 2012;38(4):449-67. Available from: http://dx.doi.org/10.1016/j.pecs.2012.03.002

[4] Naik SN, Goud V V., Rout PK, Dalai AK. Production of first and second generation biofuels: A comprehensive review. Renew Sustain Energy Rev. 2010;14(2):578-97.

[5] Mohan D, Pittman CU, Steele PH. Pyrolysis of wood/biomass for bio-oil: A critical review. Energy and Fuels. 2006;20(3):848-89.

[6] Bridgwater A V. Review of fast pyrolysis of biomass and product upgrading. Biomass and Bioenergy [Internet]. 2012;38:68-94. Available from: http://dx.doi.org/10.1016/j.biombioe.2011.01.048

[7] Rover M, Hall P, Johnston P, Smith R, Brown R. Stabilization of bio-oils using low temperature, low pressure hydrogenation. Fuel [Internet]. 2015;153:224-30. Available from: http://www.sciencedirect.com/science/article/pii/S0016236115002021

[8] Abnisa F, Arami-Niya A, Wan Daud WMA, Sahu JN, Noor IM. Utilization of oil palm tree residues to produce bio-oil and bio-char via pyrolysis. Energy Convers Manag [Internet]. 2013;76:1073-82. Available from: http://dx.doi.org/10.1016/j.enconman.2013.08.038

[9] Abnisa F, Wan Daud WMA, Arami-Niya A, Ali BS, Sahu JN. Recovery of Liquid Fuel from the Aqueous Phase of Pyrolysis Oil Using Catalytic Conversion. Energy \& Fuels [Internet]. 2014;28(5):3074-85. Available from: http://pubs.acs.org/doi/abs/10.1021/ef5003952

[10] Furimsky E. Catalytic hydrodeoxygenation. Appl Catal A Gen [Internet]. 2000;199(2):147-90. Available from: http://www.sciencedirect.com/science/article/pii/S0926860X99005554

[11] Ko CH, Park SH, Jeon JK, Suh DJ, Jeong KE, Park YK. Upgrading of biofuel by the catalytic deoxygenation of biomass. Korean J Chem Eng. 2012;29(12):1657-65.

[12] Zhang X, Zhang Q, Wang T, Li B, Xu Y, Ma L. Efficient upgrading process for production of low quality fuel from bio-oil. Fuel [Internet]. 2016;179:312-21. Available from: http://dx.doi.org/10.1016/j.fuel.2016.03.103

[13] Zhang J, Wang K, Nolte MW, Choi YS, Brown RC, Shanks BH. Catalytic Deoxygenation of Bio-Oil Model Compounds over Acid-Base Bifunctional Catalysts. ACS Catal. 2016;6(4):2608-21.

[14] Saber M, Nakhshiniev B, Yoshikawa K. A review of production and upgrading of algal bio-oil. Renew Sustain Energy Rev [Internet]. 2016;58:918-30. Available from: http://dx.doi.org/10.1016/j.rser.2015.12.342

[15] Choudhary T V., Phillips CB. Renewable fuels via catalytic hydrodeoxygenation. Appl Catal A Gen [Internet]. 2011;397(1-2):1-12. Available from: http://dx.doi.org/10.1016/j.apcata.2011.02.025

[16] Zhang Q, Chang J, Wang T, Xu Y. Review of biomass pyrolysis oil properties and upgrading research. Energy Convers Manag. 2007;48(1):87-92.

[17] Zacher AH, Olarte M V., Santosa DM, Elliott DC, Jones SB. A review and perspective of recent bio-oil hydrotreating research. Green Chem [Internet]. 2014;16(2):491-515. Available from: http://xlink.rsc.org/?DOI=C3GC41382A

[18] Williams PT, Horne PA. Characterisation of oils from the fluidised bed pyrolysis of biomass with zeolite catalyst upgrading. Biomass and Bioenergy [Internet]. 1994;7(1):223-36. Available from: http://www.sciencedirect.com/science/article/pii/096195349400064Z 
[19] Guo X-Y, Yan Y-J, Li T-C. Influence of catalyst type and regeneration on upgrading of crude bio-oil through catalytical thermal cracking. Guocheng Gongcheng Xuebao/The Chinese J Process Eng [Internet]. 2004;4(1):53-8. Available from: https://www.scopus.com/inward/record.uri?eid=2-s2.02042544073\&partnerID=40\&md5=797664aa3f35089f70ae83435bc7af39

[20] Adjaye JD, Bakhshi NN. Production of hydrocarbons by catalytic upgrading of a fast pyrolysis bio-oil. Part II: Comparative catalyst performance and reaction pathways. Fuel Process Technol. 1995;45(3):185-202.

[21] Katikaneni S, Adjaye J, Bakhshi N. Performance of aluminophosphate molecular sieve catalysts for the production of hydrocarbons from wood-derived and vegetable oils. Energy \& fuels [Internet]. 1995;(7):1065-78. Available from: http://pubs.acs.org/doi/pdf/10.1021/ef00054a021

[22] Shemfe M, Gu S, Fidalgo B. Techno-economic analysis of biofuel production via bio-oil zeolite upgrading: An evaluation of two catalyst regeneration systems. Biomass and Bioenergy [Internet]. 2017 Mar;98:18293. Available from: http://www.sciencedirect.com/science/article/pii/S0961953417300375

[23] De S, Saha B, Luque R. Hydrodeoxygenation processes: Advances on catalytic transformations of biomass derived platform chemicals into hydrocarbon fuels. Bioresour Technol [Internet]. 2015;178:108-18. Available from: http://dx.doi.org/10.1016/j.biortech.2014.09.065

[24] Duan H, Dong J, Gu X, Peng YK, Chen W, Issariyakul T, Myers WK, Li MJ, Yi N, Kilpatrick AFR, Wang Y, Zheng X, Ji S, Wang Q, Feng J, Chen D, Li Y, Buffet JC, Liu H, et al. Hydrodeoxygenation of waterinsoluble bio-oil to alkanes using a highly dispersed Pd-Mo catalyst. Nat Commun. 2017;8(1).

[25] Mortensen PM, Grunwaldt JD, Jensen PA, Knudsen KG, Jensen AD. A review of catalytic upgrading of biooil to engine fuels. Appl Catal A Gen [Internet]. 2011;407(1-2):1-19. Available from: http://dx.doi.org/10.1016/j.apcata.2011.08.046

[26] He Z, Wang X. Hydrodeoxygenation of model compounds and catalytic systems for pyrolysis bio-oils upgrading. Catal Sustain Energy, Versita [Internet]. 2012;1:28-52. Available from: http://www.degruyter.com/view/j/cse.2012.1.issue/cse-2012-0004/cse-2012-0004.xml

[27] Ruddy DA, Schaidle JA, Ferrell III JR, Wang J, Moens L, Hensley JE. Recent advances in heterogeneous catalysts for bio-oil upgrading via "ex situ catalytic fast pyrolysis": catalyst development through the study of model compounds [Internet]. Vol. 16, Green Chemistry. 2014. 454 p. Available from: http://www.scopus.com/inward/record.url?eid=2-s2.0-84893161316\&partnerID=tZOtx3y1

[28] Zhao HY, Li D, Bui P, Oyama ST. Hydrodeoxygenation of guaiacol as model compound for pyrolysis oil on transition metal phosphide hydroprocessing catalysts. Appl Catal A Gen. 2011;391(1-2):305-10.

[29] Liu C, Wang H, Karim AM, Sun J, Wang Y. Catalytic fast pyrolysis of lignocellulosic biomass. Chem Soc Rev [Internet]. 2014;43(22):7594-623. Available from: http://pubs.rsc.org/en/content/articlehtml/2014/cs/c3cs60414d\%5Cnhttp://xlink.rsc.org/?DOI=C3CS60414D

[30] Chiaramonti D, Bonini M, Fratini E, Tondi G, Gartner K, Bridgwater A V., Grimm HP, Soldaini I, Webster A, Baglioni P. Development of emulsions from biomass pyrolysis liquid and diesel and their use in engines Part 1: Emulsion production. Biomass and Bioenergy. 2003;25(1):85-99.

[31] Gollakota ARK, Reddy M, Subramanyam MD, Kishore N. A review on the upgradation techniques of pyrolysis oil. Renew Sustain Energy Rev [Internet]. 2016;58:1543-68. Available from: http://dx.doi.org/10.1016/j.rser.2015.12.180

[32] Abnisa F, Daud W.M.A. Wan WMAW, Husin WNW, Sahu JN. Utilization possibilities of palm shell as a source of biomass energy in Malaysia by producing bio-oil in pyrolysis process. Biomass and Bioenergy [Internet]. 2011;35(5):1863-72. Available from: http://dx.doi.org/10.1016/j.biombioe.2011.01.033

[33] Wang H, Male J, Wang Y. Recent advances in hydrotreating of pyrolysis bio-oil and its oxygen-containing model compounds. ACS Catal. 2013;3(5):1047-70.

[34] Huber GW, Iborra S, Corma A. Synthesis of transportation fuels from biomass: Chemistry, catalysts, and engineering. Chem Rev. 2006;106(9):4044-98.

[35] Jacobson K, Maheria KC, Kumar Dalai A. Bio-oil valorization: A review. Renew Sustain Energy Rev. 2013;23:91-106.

[36] Demirbas A. The influence of temperature on the yields of compounds existing in bio-oils obtained from biomass samples via pyrolysis. Fuel Process Technol. 2007;88(6):591-7.

[37] Debdoubi A, El Amarti A, Colacio E, Blesa MJ, Hajjaj LH. The effect of heating rate on yields and compositions of oil products from esparto pyrolysis. Int J Energy Res. 2006;30(15):1243-50.

[38] Grača I, Lopes JM, Cerqueira HS, Ribeiro MF. Bio-oils upgrading for second generation biofuels. Ind Eng Chem Res. 2013;52(1):275-87.

[39] Xiu S, Shahbazi A. Bio-oil production and upgrading research: A review. Renew Sustain Energy Rev [Internet]. 2012;16(7):4406-14. Available from: http://dx.doi.org/10.1016/j.rser.2012.04.028 
[40] Zhang X-S, Yang G-X, Jiang H, Liu W-J, Ding H-S. Mass production of chemicals from biomass-derived oil by directly atmospheric distillation coupled with co-pyrolysis. Sci Rep [Internet]. 2013;3:1120. Available from:

http://www.pubmedcentral.nih.gov/articlerender.fcgi $?$ artid=3553461\&tool=pmcentrez\&rendertype=abstract

[41] Alsbou EIDM. Pyrolysis Bio-oil as a Renewable Fuel and Source of Chemicals : its Production, Characterization and Stability. 2014;(July).

[42] Hu X, Mourant D, Gunawan R, Wu L, Wang Y, Lievens C, Li C-Z. Production of value-added chemicals from bio-oil via acid catalysis coupled with liquid-liquid extraction. RSC Adv. 2012;2(25):9366.

[43] Brammer JG, Lauer M, Bridgwater A V. Opportunities for biomass-derived "bio-oil" in European heat and power markets. Energy Policy. 2006;34(17):2871-80.

[44] Elkasabi Y, Mullen CA, Boateng AA. Distillation and isolation of commodity chemicals from bio-oil made by tail-gas reactive pyrolysis. ACS Sustain Chem Eng. 2014;2(8):2042-52.

[45] Czernik S, Bridgwater A V. Overview of applications of biomass fast pyrolysis oil. Energy \& Fuels [Internet]. 2004;18(2):590-598. Available from: http://pubs.acs.org/doi/abs/10.1021/ef034067u

[46] No SY. Application of bio-oils from lignocellulosic biomass to transportation, heat and power generation A review. Renew Sustain Energy Rev [Internet]. 2014;40:1108-25. Available from: http://dx.doi.org/10.1016/j.rser.2014.07.127

[47] Strenziok R, Hansen U, Künstner H. Combustion of Bio-Oil in a Gas Turbine. In: Progress in Thermochemical Biomass Conversion [Internet]. Blackwell Science Ltd; 2001. p. 1452-8. Available from: http://dx.doi.org/10.1002/9780470694954.ch119

[48] Yang SI, Hsu TC, Wu CY, Chen KH, Hsu YL, Li YH. Application of biomass fast pyrolysis part II: The effects that bio-pyrolysis oil has on the performance of diesel engines. Energy. 2014;66:172-80.

[49] Bandi A, Baumgart F. Stirling Engine with Flax ${ }^{\circledR}$ Burner Fuelled with Fast Pyrolysis Liquid. In: Progress in Thermochemical Biomass Conversion [Internet]. Blackwell Science Ltd; 2008. p. 1459-67. Available from: http://dx.doi.org/10.1002/9780470694954.ch120

[50] Yang Z, Kumar A, Huhnke RL. Review of recent developments to improve storage and transportation stability of bio-oil. Renew Sustain Energy Rev [Internet]. 2015 Oct;50:859-70. Available from: http://www.sciencedirect.com/science/article/pii/S1364032115004840

[51] Branca C, Di Blasi C, Galgano A. Pyrolysis of corncobs catalyzed by zinc chloride for furfural production. Ind Eng Chem Res. 2010;49(20):9743-52.

[52] Müller N, Romero R, Grandón H, Segura C. Selective Production of Formic Acid by Wet Oxidation of Aqueous-Phase Bio-oil. Energy \& Fuels [Internet]. 2016;30(12):10417-24. Available from: http://pubs.acs.org/doi/abs/10.1021/acs.energyfuels.6b01345

[53] Vitasari CR. Extraction of Bio-based Glycolaldehyde from Wood-derived Pyrolysis Oils. 2012. 1-148 p.

[54] Cooper JE, Hassan EM, Steele PH, Mitchell B. Characteristics and Performance of a Wood Preservative Produced from Pyrolysis Oil Potential Wood Preservatives from Wood-Based Pyrolysis Oil. 2015;(January).

[55] Oehr KH, Scott DS, Czernik S. Method of producing calcium salts from biomass. Google Patents; 1993.

[56] Oh S-J, Choi G-G, Kim J-S. Production of acetic acid-rich bio-oils from the fast pyrolysis of biomass and synthesis of calcium magnesium acetate deicer. J Anal Appl Pyrolysis [Internet]. 2017;124:122-9. Available from: http://dx.doi.org/10.1016/j.jaap.2017.01.032

[57] Chheda JN, Román-Leshkov Y, Dumesic JA. Production of 5-hydroxymethylfurfural and furfural by dehydration of biomass-derived mono-and poly-saccharides. Green Chem. 2007;9(4):342-50.

[58] Bennett NM, Helle SS, Duff SJB. Extraction and hydrolysis of levoglucosan from pyrolysis oil. Bioresour Technol [Internet]. 2009;100(23):6059-63. Available from: http://dx.doi.org/10.1016/j.biortech.2009.06.067

[59] Ng KS, Sadhukhan J. Process integration and economic analysis of bio-oil platform for the production of methanol and combined heat and power. Biomass and Bioenergy [Internet]. 2011;35(3):1153-69. Available from: http://dx.doi.org/10.1016/j.biombioe.2010.12.003

[60] Kim SJ, Jung SH, Kim JS. Fast pyrolysis of palm kernel shells: Influence of operation parameters on the bio-oil yield and the yield of phenol and phenolic compounds. Bioresour Technol [Internet]. 2010;101(23):9294-300. Available from: http://dx.doi.org/10.1016/j.biortech.2010.06.110

[61] Kim JS. Production, separation and applications of phenolic-rich bio-oil - A review. Bioresour Technol [Internet]. 2015;178:90-8. Available from: http://dx.doi.org/10.1016/j.biortech.2014.08.121

[62] Carlson TR, Cheng Y-T, Jae J, Huber GW. Production of green aromatics and olefins by catalytic fast pyrolysis of wood sawdust. Energy Environ Sci [Internet]. 2011;4(1):145-61. Available from: http://pubs.rsc.org/en/content/articlepdf/2011/ee/c0ee00341g\%5Cnhttp://xlink.rsc.org/?DOI=C0EE00341G

[63] Yin Q, Wang S, Li X, Guo Z, Gu Y. Review of bio-oil upgrading technologies and experimental study on 
emulsification of bio-oil and diesel. Proc - 2010 Int Conf Optoelectron Image Process ICOIP 2010. 2010;2:343-7.

[64] Zhang L, Liu R, Yin R, Mei Y. Upgrading of bio-oil from biomass fast pyrolysis in China: A review. Renew Sustain Energy Rev [Internet]. 2013;24:66-72. Available from: http://dx.doi.org/10.1016/j.rser.2013.03.027

[65] Kanaujia PK, Sharma YK, Garg MO, Tripathi D, Singh R. Review of analytical strategies in the production and upgrading of bio-oils derived from lignocellulosic biomass. J Anal Appl Pyrolysis [Internet]. 2014;105:55-74. Available from: http://dx.doi.org/10.1016/j.jaap.2013.10.004

[66] Ohta H, Yamamoto K, Hayashi M, Hamasaka G, Uozumi Y, Watanabe Y. Low temperature hydrodeoxygenation of phenols under ambient hydrogen pressure to form cyclohexanes catalysed by Pt nanoparticles supported on H-ZSM-5. Chem Commun. 2015;51(95):17000-3.

[67] Venderbosch RH, Ardiyanti AR, Wildschut J, Oasmaa A, Heeres HJ. Stabilization of biomass-derived pyrolysis oils. J Chem Technol Biotechnol. 2010;85(5):674-86.

[68] Elliott DC, Hart TR. 73 Catalytic Hydroprocessing of Chemical Models for Bio-oil. 2009;(8):631-7.

[69] Elliott DC, Hart TR, Neuenschwander GG, Rotness LJ, Zacher AH. Catalytic hydroprocessing of biomass fast pyrolysis bio-oil to produce hydrocarbon products. Environ Prog Sustain Energy. 2009;28(3):441-9.

[70] Prasomsri T, Nimmanwudipong T, Roman-Leshkov Y. Effective hydrodeoxygenation of biomass-derived oxygenates into unsaturated hydrocarbons by $\mathrm{MoO} 3$ using low $\mathrm{H} 2$ pressures. Energy Environ Sci [Internet]. 2013;6(6):1732-8. Available from: http://dx.doi.org/10.1039/C3EE24360E

[71] Chen CJ, Lee WS, Bhan A. Mo2C catalyzed vapor phase hydrodeoxygenation of lignin-derived phenolic compound mixtures to aromatics under ambient pressure. Appl Catal A Gen. 2016;510:42-8.

[72] Joshi N, Lawal A. Hydrodeoxygenation of acetic acid in a microreactor. Chem Eng Sci [Internet]. 2012;84:761-71. Available from: http://dx.doi.org/10.1016/j.ces.2012.09.018

[73] Prasomsri T, Shetty M, Murugappan K, Román-Leshkov Y. Insights into the catalytic activity and surface modification of $\mathrm{MoO} 3$ during the hydrodeoxygenation of lignin-derived model compounds into aromatic hydrocarbons under low hydrogen pressures. Energy Environ Sci [Internet]. 2014;7(8):2660. Available from: http://xlink.rsc.org/?DOI=C4EE00890A

[74] Lee WS, Wang Z, Wu RJ, Bhan A. Selective vapor-phase hydrodeoxygenation of anisole to benzene on molybdenum carbide catalysts. J Catal [Internet]. 2014;319:44-53. Available from: http://dx.doi.org/10.1016/j.jcat.2014.07.025

[75] Zhou G, Jensen PA, Le DM, Knudsen NO, Jensen AD. Atmospheric Hydrodeoxygenation of Biomass Fast Pyrolysis Vapor by MoO3. ACS Sustain Chem Eng. 2016;4(10):5432-40.

[76] Shetty M, Murugappan K, Prasomsri T, Green WH, Román-Leshkov Y. Reactivity and stability investigation of supported molybdenum oxide catalysts for the hydrodeoxygenation (HDO) of m-cresol. J Catal [Internet]. 2015;331:86-97. Available from: http://dx.doi.org/10.1016/j.jcat.2015.07.034

[77] Nimmanwudipong T, Runnebaum RC, Block DE, Gates BC. Catalytic Conversion of Guaiacol Catalyzed by Platinum Supported on Alumina: Reaction Network Including Hydrodeoxygenation Reactions. Energy \& Fuels [Internet]. 2011 Aug 18;25(8):3417-27. Available from: http://dx.doi.org/10.1021/ef200803d

[78] Zhu X, Lobban LL, Mallinson RG, Resasco DE. Bifunctional transalkylation and hydrodeoxygenation of anisole over a Pt/HBeta catalyst. J Catal [Internet]. 2011;281(1):21-9. Available from: http://dx.doi.org/10.1016/j.jcat.2011.03.030

[79] Nimmanwudipong T, Runnebaum RC, Block DE, Gates BC. Catalytic reactions of guaiacol: Reaction network and evidence of oxygen removal in reactions with hydrogen. Catal Letters. 2011;141(6):779-83.

[80] Nimmanwudipong T, Aydin C, Lu J, Runnebaum RC, Brodwater KC, Browning ND, Block DE, Gates BC. Selective hydrodeoxygenation of guaiacol catalyzed by platinum supported on magnesium oxide. Catal Letters. 2012;142(10):1190-6.

[81] Runnebaum RC, Nimmanwudipong T, Block DE, Gates BC. Catalytic conversion of compounds representative of lignin-derived bio-oils: a reaction network for guaiacol, anisole, 4-methylanisole, and cyclohexanone conversion catalysed by Pt $/ \gamma-\mathrm{Al} 2 \mathrm{O}$. Catal Sci Technol. 2012;2(1):113.

[82] Zanuttini MS, Dalla Costa BO, Querini CA, Peralta MA. Hydrodeoxygenation of m-cresol with Pt supported over mild acid materials. Appl Catal A Gen [Internet]. 2014;482:352-61. Available from: http://dx.doi.org/10.1016/j.apcata.2014.06.015

[83] Zanuttini MS, Lago CD, Querini CA, Peralta MA. Deoxygenation of m-cresol on Pt/??-A12O3 catalysts. Catal Today [Internet]. 2013;213:9-17. Available from: http://dx.doi.org/10.1016/j.cattod.2013.04.011

[84] Olcese RN, Francois J, Bettahar MM, Petitjean D, Dufour A. Hydrodeoxygenation of guaiacol, a surrogate of lignin pyrolysis vapors, over iron based catalysts: Kinetics and modeling of the lignin to aromatics integrated process. Energy and Fuels. 2013;27(2):975-84. 
[85] Olcese R, Bettahar MM, Malaman B, Ghanbaja J, Tibavizco L, Petitjean D, Dufour A. Gas-phase hydrodeoxygenation of guaiacol over iron-based catalysts. Effect of gases composition, iron load and supports (silica and activated carbon). Appl Catal B Environ [Internet]. 2013;129:528-38. Available from: http://dx.doi.org/10.1016/j.apcatb.2012.09.043

[86] Olcese RN, Bettahar M, Petitjean D, Malaman B, Giovanella F, Dufour A. Gas-phase hydrodeoxygenation of guaiacol over Fe/SiO2 catalyst. Appl Catal B Environ [Internet]. 2012 Apr 5;115-116:63-73. Available from: http://www.sciencedirect.com/science/article/pii/S0926337311005662

[87] Ausavasukhi A, Huang Y, To AT, Sooknoi T, Resasco DE. Hydrodeoxygenation of m-cresol over galliummodified beta zeolite catalysts. J Catal [Internet]. 2012;290:90-100. Available from: http://dx.doi.org/10.1016/j.jcat.2012.03.003

[88] Wan S, Pham T, Zhang S, Lobban L, Resasco D, Mallinson R. Direct catalytic upgrading of biomass pyrolysis vapors by a dual function $\mathrm{Ru} / \mathrm{TiO}_{2}$ catalyst. AIChE J [Internet]. 2013 Jul [cited 2017 May 1];59(7):2275-85. Available from: http://doi.wiley.com/10.1002/aic.14038

[89] Ren H, Chen Y, Huang Y, Deng W, Vlachos DG, Chen JG. Tungsten carbides as selective deoxygenation catalysts: experimental and computational studies of converting $\mathrm{C} 3$ oxygenates to propene. Green Chem [Internet]. 2014;16(2):761-9. Available from: http://xlink.rsc.org/?DOI=C3GC41256C

[90] Chandra-Sekhar V, Shee D, Maity SK. Kinetics of hydrodeoxygenation of octanol over supported nickel catalysts: a mechanistic study. RSC Adv [Internet]. 2014;4(78):41612-21. Available from: http://dx.doi.org/10.1039/C4RA06826B\%5Cnhttp://xlink.rsc.org/?DOI=C4RA06826B

[91] Karnjanakom S, Bayu A, Hao X, Kongparakul S, Samart C, Abudula A, Guan G. Selectively catalytic upgrading of bio-oil to aromatic hydrocarbons over $\mathrm{Zn}$, Ce or Ni-doped mesoporous rod-like alumina catalysts. J Mol Catal A Chem [Internet]. 2016;421:235-44. Available from: http://dx.doi.org/10.1016/j.molcata.2016.06.001

[92] Sun J, Karim AM, Zhang H, Kovarik L, Li XS, Hensley AJ, McEwen JS, Wang Y. Carbon-supported bimetallic Pd-Fe catalysts for vapor-phase hydrodeoxygenation of guaiacol. J Catal [Internet]. 2013;306:4757. Available from: http://dx.doi.org/10.1016/j.jcat.2013.05.020

[93] Do PTM, Foster AJ, Chen J, Lobo RF. Bimetallic effects in the hydrodeoxygenation of meta-cresol on $\gamma$ Al2O3 supported Pt-Ni and Pt-Co catalysts. Green Chem. 2012;14(5):1388.

[94] Resasco DE. Anisole and Guaiacol Hydrodeoxygenation over Monolithic Pt À Sn Catalysts. 2011;25:415562.

[95] Wu SK, Lai PC, Lin YC. Atmospheric hydrodeoxygenation of guaiacol over nickel phosphide catalysts: Effect of phosphorus composition. Catal Letters. 2014;144(5):878-89.

[96] Yang J, Li S, Zhang L, Liu X, Wang J, Pan X, Li N, Wang A, Cong Y, Wang X, Zhang T. Hydrodeoxygenation of furans over $\mathrm{Pd}-\mathrm{FeOx} / \mathrm{SiO} 2$ catalyst under atmospheric pressure. Appl Catal B Environ. 2017;201:266-77.

[97] Wu SK, Lai PC, Lin YC, Wan HP, Lee HT, Chang YH. Atmospheric hydrodeoxygenation of guaiacol over alumina-, zirconia-, and silica-supported nickel phosphide catalysts. ACS Sustain Chem Eng. 2013;1(3):349-58.

[98] Bui P, Cecilia JA, Oyama ST, Takagaki A, Infantes-Molina A, Zhao H, Li D, Rodríguez-Castellón E, Jiménez López A. Studies of the synthesis of transition metal phosphides and their activity in the hydrodeoxygenation of a biofuel model compound. J Catal [Internet]. 2012;294:184-98. Available from: http://dx.doi.org/10.1016/j.jcat.2012.07.021

[99] Bui PP, Takagaki A, Kikuchi R, Oyama ST. Kinetic and Infrared Spectroscopy Study of Hydrodeoxygenation of 2-Methyltetrahydrofuran on a Nickel Phosphide Catalyst at Atmospheric Pressure. ACS Catal [Internet]. 2016; acscatal.6b02396. Available from: http://pubs.acs.org/doi/abs/10.1021/acscatal.6b02396

[100] Fan L, Zhang Y, Liu S, Zhou N, Chen P, Cheng Y, Addy M, Lu Q, Omar MM, Liu Y, Wang Y, Dai L, Anderson E, Peng P, Lei H, Ruan R. Bio-oil from fast pyrolysis of lignin: Effects of process and upgrading parameters. Bioresour Technol [Internet]. 2017;241:1118-26. Available from: http://www.sciencedirect.com/science/article/pii/S0960852417307976

[101] Li X, Luo X, Jin Y, Li J, Zhang H, Zhang A, Xie J. Heterogeneous sulfur-free hydrodeoxygenation catalysts for selectively upgrading the renewable bio-oils to second generation biofuels. Renew Sustain Energy Rev [Internet]. 2018;82:3762-97. Available from: http://www.sciencedirect.com/science/article/pii/S1364032117314557

[102] Nolte MW, Shanks BH. A Perspective on Catalytic Strategies for Deoxygenation in Biomass Pyrolysis. Energy Technol. 2017;5(1):7-18. 
[103] Yang J, Li S, Zhang L, Liu X, Wang J, Pan X, Li N, Wang A, Cong Y, Wang X, Zhang T. Hydrodeoxygenation of furans over $\mathrm{Pd}-\mathrm{FeOx} / \mathrm{SiO} 2$ catalyst under atmospheric pressure. Appl Catal B Environ [Internet]. 2017 Feb;201:266-77. Available from: http://www.sciencedirect.com/science/article/pii/S0926337316306531

[104] Yakovlev VA, Khromova SA, Sherstyuk O V., Dundich VO, Ermakov DY, Novopashina VM, Lebedev MY, Bulavchenko O, Parmon VN. Development of new catalytic systems for upgraded bio-fuels production from bio-crude-oil and biodiesel. Catal Today. 2009;144(3-4):362-6.

[105] Laurent E, Delmon B. Influence of water in the deactivation of a sulfided NiMo $\gamma-\mathrm{Al} 2 \mathrm{O} 3$ catalyst during hydrodeoxygenation. J Catal. 1994;146(1).

[106] Popov A, Kondratieva E, Gilson JP, Mariey L, Travert A, Maugé F. IR study of the interaction of phenol with oxides and sulfided CoMo catalysts for bio-fuel hydrodeoxygenation. Catal Today [Internet]. 2011;172(1):132-5. Available from: http://dx.doi.org/10.1016/j.cattod.2011.02.010

[107] Saidi M, Samimi F, Karimipourfard D, Nimmanwudipong T, Gates BC, Rahimpour MR. Upgrading of lignin-derived bio-oils by catalytic hydrodeoxygenation. Energy Environ Sci [Internet]. 2014;7(1):103-29. Available from: http://xlink.rsc.org/?DOI=C3EE43081B

[108] Bu Q, Lei H, Zacher AH, Wang L, Ren S, Liang J, Wei Y, Liu Y, Tang J, Zhang Q, Ruan R. A review of catalytic hydrodeoxygenation of lignin-derived phenols from biomass pyrolysis. Bioresour Technol [Internet]. 2012;124:470-7. Available from: http://dx.doi.org/10.1016/j.biortech.2012.08.089

[109] Asadieraghi M, Wan Daud WMA, Abbas HF. Model compound approach to design process and select catalysts for in-situ bio-oil upgrading. Renew Sustain Energy Rev [Internet]. 2014;36:286-303. Available from: http://dx.doi.org/10.1016/j.rser.2014.04.050

[110] Moon JS, Kim EG, Lee YK. Active sites of Ni2P/SiO2 catalyst for hydrodeoxygenation of guaiacol: A joint XAFS and DFT study. J Catal. 2014;311:144-52.

[111] Tran N, Uemura Y, Chowdhury S, Ramli A. A Review of Bio-Oil Upgrading by Catalytic Hydrodeoxygenation. Appl Mech Mater [Internet]. 2014;625:255-8. Available from: http://www.scientific.net/AMM.625.255

[112] De Oliveira LP, Hudebine D, Guillaume D, Verstraete JJ. A Review of Kinetic Modeling Methodologies for Complex Processes. Oil Gas Sci Technol. 2016;71(3).

[113] Elliott DC, Hart TR, Neuenschwander GG, Rotness LJ, Olarte M V., Zacher AH, Solantausta Y. Catalytic hydroprocessing of fast pyrolysis bio-oil from pine sawdust. Energy and Fuels. 2012;26(6):3891-6.

[114] Mu W, Ben H, Ragauskas A, Deng Y. Lignin Pyrolysis Components and Upgrading-Technology Review. Bioenergy Res. 2013;6(4):1183-204.

[115] Bykova M V., Zavarukhin SG, Trusov LI, Yakovlev VA. Guaiacol hydrodeoxygenation kinetics with catalyst deactivation taken into consideration. Kinet Catal [Internet]. 2013;54(1):40-8. Available from: http://link.springer.com/10.1134/S0023158413010023

[116] Mukundan S, Konarova M, Atanda L, Ma Q, Beltramini J. Guaiacol hydrodeoxygenation reaction catalyzed by highly dispersed, single layered $\mathrm{MoS}_{2}$ /C. Catal Sci Technol [Internet]. 2015;5(9):4422-32. Available from: http://xlink.rsc.org/?DOI=C5CY00607D

[117] Peters JE, Carpenter JR, Dayton DC. Anisole and guaiacol hydrodeoxygenation reaction pathways over selected catalysts. Energy and Fuels. 2015;29(2):909-16.

[118] Yong TLK, Yukihiko M. Kinetic analysis of guaiacol conversion in sub- and supercritical water. Ind Eng Chem Res. 2013;52(26):9048-59.

[119] Shin-Kuan, W. et al. Atmospheric Hydrodeoxygenation of Guaiacol over Alumina-, Zirconia-, and SilicaSupported Nickel Phosphide Catalysts. 2013;1:349-58.

[120] Gao D, Xiao Y, Varma A. Guaiacol Hydrodeoxygenation over Platinum Catalyst: Reaction Pathways and Kinetics. Ind Eng Chem Res. 2015;54(43):10638-44.

[121] Lee CR, Yoon JS, Suh YW, Choi JW, Ha JM, Suh DJ, Park YK. Catalytic roles of metals and supports on hydrodeoxygenation of lignin monomer guaiacol. Catal Commun [Internet]. 2012;17:54-8. Available from: http://dx.doi.org/10.1016/j.catcom.2011.10.011 